\title{
Nutrition and cancer: A review of the evidence for an anti-cancer diet Michael S Donaldson*
}

\author{
Address: Director of Research, Hallelujah Acres Foundation, 13553 Vantage Hwy, Ellensburg, WA 98926, USA \\ Email: Michael S Donaldson* - michael@ hacres.com \\ * Corresponding author
}

Published: 20 October 2004

Nutrition Journal 2004, 3:19 doi:10.1/86/1475-289/-3-19

This article is available from: http://www.nutritionj.com/content/3/I/I9

(C) 2004 Donaldson; licensee BioMed Central Ltd.

This is an open-access article distributed under the terms of the Creative Commons Attribution License (http://creativecommons.org/licenses/by/2.0), which permits unrestricted use, distribution, and reproduction in any medium, provided the original work is properly cited.
Received: 28 September 2004

Accepted: 20 October 2004

\begin{abstract}
It has been estimated that 30-40 percent of all cancers can be prevented by lifestyle and dietary measures alone. Obesity, nutrient sparse foods such as concentrated sugars and refined flour products that contribute to impaired glucose metabolism (which leads to diabetes), low fiber intake, consumption of red meat, and imbalance of omega 3 and omega 6 fats all contribute to excess cancer risk. Intake of flax seed, especially its lignan fraction, and abundant portions of fruits and vegetables will lower cancer risk. Allium and cruciferous vegetables are especially beneficial, with broccoli sprouts being the densest source of sulforophane. Protective elements in a cancer prevention diet include selenium, folic acid, vitamin B-I2, vitamin D, chlorophyll, and antioxidants such as the carotenoids ( $\alpha$-carotene, $\beta$-carotene, lycopene, lutein, cryptoxanthin). Ascorbic acid has limited benefits orally, but could be very beneficial intravenously. Supplementary use of oral digestive enzymes and probiotics also has merit as anticancer dietary measures. When a diet is compiled according to the guidelines here it is likely that there would be at least a $60-70$ percent decrease in breast, colorectal, and prostate cancers, and even a 40-50 percent decrease in lung cancer, along with similar reductions in cancers at other sites. Such a diet would be conducive to preventing cancer and would favor recovery from cancer as well.
\end{abstract}

\section{Review Background}

The field of investigation of the role of nutrition in the cancer process is very broad. It is becoming clearer as research continues that nutrition plays a major role in cancer. It has been estimated by the American Institute for Cancer Research and the World Cancer Research Fund that 30-40 percent of all cancers can be prevented by appropriate diets, physical activity, and maintenance of appropriate body weight [1]. It is likely to be higher than this for some individual cancers.
Most of the research on nutrition and cancer has been reductionist; that is, a particular food or a nutrient has been studied in relation to its impact on tumor formation/regression or some other end point of cancer at a particular site in the body. These studies are very helpful in seeing the details of the mechanisms of disease. However, they do not help give an overall picture of how to prevent cancer on a dietary level. Even less, they tell little of how to eat when a person already has a cancer and would like to eat a diet that is favorable to their recovery.

This review will focus on those dietary factors which has been shown to be contribute to increased risk of cancer 
and then on those additional protective dietary factors which reduce cancer risk. Finally, some whole-diet studies will be mentioned which give a more complete picture of how these individual factors work together to reduce cancer risk.

\section{Over Consumption of Energy (Calories)}

Eating too much food is one of the main risk factors for cancer. This can be shown two ways: (1) by the additional risks of malignancies caused by obesity, and (2) by the protective effect of eating less food.

Obesity has reached epidemic proportions in the United States. Sixty-four percent of the adult population is overweight or obese [2]. About 1 in 50 are now severely obese (BMI $>40 \mathrm{~kg} / \mathrm{m} 2$ ) [3]. Mokdad et al [4] found that poor diet and physical inactivity was the second leading cause of death (400,000 per year in the USA), and would likely overtake tobacco as the leading cause of death.

It was estimated in a recent study, from a prospective cancer prevention cohort, that overweight and obesity accounted for 14 percent of all cancer deaths in men and 20 percent of those in women [5]. Significant positive associations were found between obesity and higher death rates for the following cancers: esophagus, colon and rectum, liver, gallbladder, pancreas, kidney, stomach (in men), prostate, breast, uterus, cervix, and ovary [5]. The authors estimated that over 90,000 cancer deaths per year could be avoided if the adult population all maintained a normal weight (BMI < 25.0) [5]. Clearly, obesity is a major risk factor for cancer.

On the other side, careful menu planning brings about an approach entitled CRON-Calorie Restriction with Optimal Nutrition. The basic idea is to eat a reduced amount of food (about 70-80 percent of the amount required to maintain "normal" body weight) while still consuming all of the necessary amounts of vitamins, minerals, and other necessary nutrients. The only restriction is the total amount of energy (calories) that is consumed. While being difficult to practice, this approach has a lot of scientific merit for being able to extend average life spans of many species of animals including rats, mice, fish, and possibly primates (currently being tested). Along with this life span extension is a reduction in chronic diseases that are common to mankind, reviewed in Hursting et al [6]. A recent meta-analysis of 14 experimental studies found that energy restriction resulted in a 55\% reduction in spontaneous tumors in laboratory mice [7]. Calorie restriction inhibited induced mammary tumors in mice [8] and suppressed implanted tumor growth and prolonged survival in energy restricted mice [9]. Among Swedish women who had been hospitalized for anorexia nervosa (definitely lower caloric intake, but not adequate nutrition) prior to age 40 , there was a $23 \%$ lower incidence of breast cancer for nulliparous women and a $76 \%$ lower incidence for parous women [10]. So, too many calories is definitely counter-productive, and slightly less than normal is very advantageous.

\section{Glucose Metabolism}

Refined sugar is a high energy, low nutrient food - junk food. "Unrefined" sugar (honey, evaporated cane juice, etc) is also very concentrated and is likely to contribute to the same problems as refined sugar. Refined wheat flour products are lacking the wheat germ and bran, so they have 78 percent less fiber, an average of 74 percent less of the $\mathrm{B}$ vitamins and vitamin $\mathrm{E}$, and 69 percent less of the minerals (USDA Food database, data not shown). Concentrated sugars and refined flour products make up a large portion of the carbohydrate intake in the average American diet. One way to measure the impact of these foods on the body is through the glycemic index.

The glycemic index is an indication of the blood sugar response of the body to a standardized amount of carbohydrate in a food. The glycemic load takes into account the amount of food eaten. An international table of the glycemic index and glycemic load of a wide variety of foods has been published [11].

Case-control studies and prospective population studies have tested the hypothesis that there is an association between a diet with a high glycemic load and cancer. The case control studies have found consistent increased risk of a high glycemic load with gastric [12], upper aero digestive tract [13], endometrial [14], ovarian [15], colon or colorectal cancers $[16,17]$. The prospective studies' results have been mixed. Some studies showed increased risk of cancer in the whole cohort with high glycemic load [1820]; some studies found only increased risk among subgroups such as sedentary, overweight subjects [21-24]; other studies concluded that there was no increased risk for any of their cohort [25-28]. Even though there were no associations between glycemic load and colorectal, breast, or pancreatic cancer in the Nurses' Health Study there was still a strong link between diabetes and colorectal cancer [29].

Perhaps the dietary glycemic load is not consistently related to glucose disposal and insulin metabolism due to individual's different responses to the same glycemic load. Glycated hemoglobin $\left(\mathrm{HbA}_{1 \mathrm{c}}\right)$ is a time-integrated measurement of glucose control, and indirectly, of insulin levels. Increased risk in colorectal cancer was seen in the EPIC-Norfolk study with increasing $\mathrm{HbA}_{1 \mathrm{c}}$; subjects with known diabetes had a three-fold increased risk of colorectal cancer [30]. In a study of a cohort in Washington county, Maryland, increased risk of colorectal cancer was 
seen in subjects with elevated $\mathrm{HbA}_{1 \mathrm{c}^{\prime}} \mathrm{BMI}>30 \mathrm{~kg} / \mathrm{m}^{2}$, or who used medications to control diabetes [31]. However, glycated hemoglobin was not found to be associated with increased risk of colorectal cancer in a small nested casecontrol study within the Nurses' Health Study [32]. Elevated fasting glucose, fasting insulin, 2 hour levels of glucose and insulin after an oral glucose challenge, and larger waist circumference were associated with a higher risk of colorectal cancer [33]. In multiple studies diabetes has been linked with increased risk of colorectal cancer [3437], endometrial cancer [38], and pancreatic cancer $[35,39]$. It is clear that severe dysregulation of glucose metabolism is a risk factor for cancer. Foods which contribute to hyperinsulinemia, such as refined sugar, foods containing refined sugar, and refined flour products should be avoided and eliminated from a cancer protective diet.

\section{Low Fiber}

Unrefined plant foods typically have an abundance of fiber. Dairy products, eggs, and meat all have this in common - they contain no fiber. Refined grain products also have most of the dietary fiber removed from them. So, a diet high in animal products and refined grains (a typical diet in the USA) is low in fiber. In prospective health studies low fiber was not found to be a risk for breast cancer [25]. It is possible that fiber measurements are just a surrogate measure for unrefined plant food intake. Slattery et al [40] found an inverse correlation between vegetable, fruit and whole grain intake plant food intake and rectal cancer, while refined grains were associated with increased risk of rectal cancer. A threshold of about 5 daily servings of vegetables was needed to reduce cancer risk and the effect was stronger among older subjects [40]. Many other nutrients are co-variants with fiber, including folic acid, which is covered in detail below.

\section{Red Meat}

Red meat has been implicated in colon and rectal cancer. A Medline search in February 2003 uncovered 26 reports of human studies investigating the link between diet and colon or colorectal cancer. Of the 26 reports, 21 of them reported a significant positive relationship between red meat and colon or colorectal cancer [17,41-64]. A recent meta-analysis also found red meat, and processed meat, to be significantly associated with colorectal cancer [65]. Meat, and the heterocyclic amines formed in cooking, have been correlated to breast cancer in a case-control study in Uruguay as well [66].

\section{Omega 3:6 Ratio Imbalance}

Omega 3 fats (alpha-linolenic acid, EPA, DHA) have been shown in animal studies to be protect from cancer, while omega 6 fats (linoleic acid, arachidonic acid) have been found to be cancer promoting fats. Now there have been several studies that have tested this hypothesis in relation to breast cancer, summarized in Table 1. Except for the study by London et al [67], all of these studies found an association between a higher ratio of N-3 to N-6 fats and reduced risk of breast cancer. Long chain N-3 and N-6 fats have a different effect on the breast tumor suppressor genes BRCA1 and BRCA2. Treatment of breast cell cultures with N-3 fats (EPA or DHA) results in increased expression of these genes while arachadonic acid had no effect [68]. Flax seed oil and DHA (from an algae source) both can be used to increase the intake of N-3 fat, with DHA being a more efficient, sure source.

\section{Flax seed}

Flax seed provides all of the nutrients from this small brown or golden hard-coated seed. It is an excellent source of dietary fiber, omega 3 fat (as alpha-linolenic acid), and lignans. The lignans in flax seed are metabolized in the digestive tract to enterodiol and enterolactone, which have estrogenic activity. In fact, flax seed is a more potent source of phytoestrogens than soy products, as flax seed intake caused a bigger change in the excretion of 2 hydroxyestrone compared to soy protein [69].

Ground flax seeds have been studied for its effect on cancer, including several excellent studies by Lilian Thompson's research group at the University of Toronto. In one study the flax seed, its lignan fraction, or the oil were added to the diet of mice who had previously been administered a chemical carcinogen to induce cancer. All three treatments reduced the established tumor load; the lignan fraction containing secoisolariciresinol diglycoside (SDG) and the flax seed also reduced metastasis [70]. In another study the flax lignan SDG was fed to mice starting 1 week after treatment with the carcinogen dimethylbenzanthracene. The number of tumors per rat was reduced by $46 \%$ compared to the control in this study [71]. Flax or its lignan (SDG) were tested to see if they would prevent melanoma metastasis. The flax or lignan fraction were fed to mice two weeks before and after injection of melanoma cells. The flax treatment (at 2.5, 5, or $10 \%$ of diet intake) resulted in a 32, 54, and 63 percent reduction in the number of tumors, compared to the control [72]. The SDG, fed at amounts equivalent to the amount in 2.5, 5, or $10 \%$ flax seed, also reduced the tumor number, from a median number of 62 in the control group to 38,36 , and 29 tumors per mouse in the SDG groups, respectively [73].

More recently Thompson's research group studied mice that were injected with human breast cancer cells. After the injection the mice were fed a basal diet (lab mouse chow) for 8 weeks while the tumors grew. Then one group continued the basal diet and another was fed a 10\% flax 
Table I: Breast Cancer and Omega 3:6 Ratio.

\begin{tabular}{|c|c|c|c|c|c|c|}
\hline Reference & $\begin{array}{l}\text { \# of cases wl } \\
\text { breast } \\
\text { cancer }\end{array}$ & \# of controls & $\begin{array}{l}\text { Post / pre } \\
\text { Menopausal }\end{array}$ & $\begin{array}{l}\text { Measure of } n-3 / \\
n-6 \text { fat }\end{array}$ & Outcome & $\begin{array}{l}\text { Odds ratio (95\% } \\
\text { Confidence Interval) }\end{array}$ \\
\hline \multirow[t]{2}{*}{ [183] } & 565 & $\begin{array}{l}554 \text { (population } \\
\text { and hospital) }\end{array}$ & Pre \& post & Diet FFQ & $\begin{array}{l}\uparrow N 3 / N 6 \text { ratio in } \\
\text { premenopausal women }= \\
\text { Non-signif. } \downarrow \text { Breast cancer } \\
\text { risk }\end{array}$ & $0.59(0.29-1.19)$ \\
\hline & & & & & $\begin{array}{l}\text { In study site with population } \\
\text { controls, find } \uparrow N 3 / \mathrm{N} 6 \text { ratio } \\
=\text { Signif } \downarrow \text { Breast Cancer risk }\end{array}$ & $0.50(0.27,0.95)$ \\
\hline [184] & $\begin{array}{l}\text { EURAMIC } \\
\text { study }\end{array}$ & $\begin{array}{l}\text { Nested case- } \\
\text { control study in } \\
\text { population study }\end{array}$ & Post & Adipose tissue & $\begin{array}{l}4 \text { out of } 5 \text { centers showed } \\
\uparrow \mathrm{N} 3 / \mathrm{N} 6 \text { ratio }=\downarrow \text { Breast } \\
\text { Cancer risk }\end{array}$ & $\begin{array}{l}0.65(p \text { for trend }= \\
0.55)\end{array}$ \\
\hline \multirow[t]{2}{*}{ [185] } & 241 & $\begin{array}{l}88 \mathrm{w} / \text { benign } \\
\text { breast disease }\end{array}$ & Both & Adipose tissue & $\uparrow D H A=\downarrow$ Breast cancer & $0.31(0.13-0.75)$ \\
\hline & & & & & $\begin{array}{l}\uparrow \text { Ratio of long chain N-3:N-6 } \\
\text { fat }=\downarrow \text { Breast cancer }\end{array}$ & $0.33(0.17-0.66)$ \\
\hline \multirow[t]{2}{*}{ [186] } & 73 & $74 \mathrm{w} /$ macromastia & $?$ & Adipose tissue & $\begin{array}{l}\text { N-6 fat content signif. higher } \\
\text { in cases }\end{array}$ & $P=0.02$ \\
\hline & & & & & $\begin{array}{l}\text { For given level of } \mathrm{N}-6 \text { fat, } \\
\text { EPA and DHA had a } \\
\text { protective effect }\end{array}$ & $P=0.06$ \\
\hline [187] & $\begin{array}{l}\text { 7I (within } \\
\text { ORDET study) }\end{array}$ & $\begin{array}{l}\text { I } 42 \text { (nested case } \\
\text { control) }\end{array}$ & Post & RBC membranes & $\uparrow \mathrm{DHA}=\downarrow$ Breast cancer & $0.44(0.21-0.92)$ \\
\hline [67] & 380 & 397 & Post & Adipose tissue & $\begin{array}{l}\text { No associations between } \mathrm{N} \text { - } \\
3: \mathrm{N}-6 \text { ratio and breast } \\
\text { cancer }\end{array}$ & \\
\hline \multirow[t]{2}{*}{ [188] } & $\begin{array}{l}314 \text { (within } \\
\text { Singapore } \\
\text { Chinese Health } \\
\text { study) }\end{array}$ & & & Diet, FFQ & $\begin{array}{l}\uparrow \text { Intake of } \mathrm{N}-3 \text { fat from fish / } \\
\text { shellfish }=\downarrow \text { Breast cancer, } \\
\text { for all } 3 \text { highest quartiles }\end{array}$ & $0.74(0.58-0.94)$ \\
\hline & & & & & $\begin{array}{l}\text { Among women in lowest } \\
\text { quartile of N-3 fat intake, } \\
\uparrow N-6 \text { fat intake }=\downarrow \text { Breast } \\
\text { cancer }\end{array}$ & $1.87(1.06-3.27)$ \\
\hline
\end{tabular}

seed diet. The flax seed reduced the tumor growth rate and reduced metastasis by $45 \%$ [74].

Flax seed has been shown to enhance mammary gland morphogenesis or differentiation in mice. Nursing dams were fed the $10 \%$ flax seed diet (or an equivalent amount of SDG). After weaning the offspring mice were fed a regular mouse chow diet. Researchers then examined the female offspring and found an increased number of terminal end buds and terminal ducts in their mammary glands with more epithelial cell proliferation, all demonstrating that mammary gland differentiation was enhanced [75]. When these female offspring were challenged with a carcinogen to induce mammary gland tumors there were significantly lower incidence of tumors $31 \%$ and $42 \%$ lower in the flax seed and SDG groups, respectively), significantly lower tumor load (51\% and 62\% lower in the flax seed and SDG groups, respectively), significantly lower mean tumor size (44\% and $68 \%$ lower in the flax seed and SDG groups, respectively), and significantly lower tumor number ( $47 \%$ and $45 \%$ lower in the flax seed and SDG groups, respectively) [76]. So, flax seed and its lignan were able to reduce tumor growth (both in number and size of tumors), prevent metastasis, and even cause increased differentiation of mouse mammary tissue in suckling mice, making the offspring less susceptible to carcinogenesis even when not consuming any flax products.

Other researchers have tested flax seed and prostate cancer. In an animal model using mice, Lin et al [77] found that a diet supplemented with $5 \%$ flax inhibited the growth and development of prostate cancer in their experimental mouse model. A pilot study of 25 men who were scheduled for prostatectomy surgery were instructed to eat a low-fat diet (20\% or less of energy intake) and to supplement with $30 \mathrm{~g}$ of ground flaxseed per day. During the follow-up of an average of 34 days there were significant changes in serum cholesterol, total testosterone, and the free androgen index [78]. The mean proliferation index of the experimental group was significantly lower and apop- 
totic indexes higher compared to historical matched controls. Ground flax seed may be a very beneficial food for men battling prostate cancer. However, a meta-analysis of nine cohort and case-control studies revealed an association between flax seed oil intake or high blood levels of alpha-linolenic acid and prostate cancer risk [79]. It is quite likely that the lignans in flax seed are a major component of flax's anti-cancer effects so that flax oil without the lignans is not very beneficial. Some brands of flax seed oil retain some of the seed particulate because of the beneficial properties of the lignans.

\section{Fruits and Vegetables}

One of the most important messages of modern nutrition research is that a diet rich in fruits and vegetables protects against cancer. (The greatest message is that this same diet protects against almost all other diseases, too, including cardiovascular disease and diabetes.) There are many mechanisms by which fruits and vegetables are protective, and an enormous body of research supports the recommendation for people to eat more fruits and vegetables.

Block et al [80] reviewed about 200 studies of cancer and fruit and vegetable intake. A statistically significant protective effect of fruits and vegetables was found in 128 of 156 studies that gave relative risks. For most cancers, people in the lower quartile (1/4 of the population) who ate the least amount of fruits and vegetables had about twice the risk of cancer compared to those who in the upper quartile who ate the most fruits and vegetables. Even in lung cancer, after accounting for smoking, increasing fruits and vegetables reduces lung cancer; an additional 20 to 33 percent reduction in lung cancers is estimated [1].

Steinmetz and Potter reviewed the relationship between fruits, vegetables, and cancer in 206 human epidemiologic studies and 22 animal studies [81]. They found "the evidence for a protective effect of greater vegetable and fruit consumption is consistent for cancers of the stomach, esophagus, lung, oral cavity and pharynx, endometrium, pancreas, and colon." Vegetables, and particularly raw vegetables, were found to be protective; $85 \%$ of the studies that queried raw vegetable consumption found a protective effect. Allium vegetables, carrots, green vegetables, cruciferous vegetables, and tomatoes also had a fairly consistent protective effect [81]. Allium vegetables (garlic, onion, leeks, and scallions) are particularly potent and have separately been found to be protective for stomach and colorectal cancers $[82,83]$ and prostate cancer [84].

There are many substances that are protective in fruits and vegetables, so that the entire effect is not very likely to be due to any single nutrient or phytochemical. Steinmetz and Potter list possible protective elements: dithiolth- iones, isothiocyanates, indole-32-carbinol, allium compounds, isoflavones, protease inhibitors, saponins, phytosterols, inositol hexaphosphate, vitamin C, Dlimonene, lutein, folic acid, beta carotene (and other carotenoids), lycopene, selenium, vitamin E, flavonoids, and dietary fiber [81].

A joint report by the World Cancer Research Fund and the American Institute for Cancer Research found convincing evidence that a high fruit and vegetable diet would reduce cancers of the mouth and pharynx, esophagus, lung, stomach, and colon and rectum; evidence of probable risk reduction was found for cancers of the larynx, pancreas, breast, and bladder [1].

Many of the recent reports from prospective populationbased studies of diet and cancer have not found the same protective effects of fruits and vegetables that were reported earlier in the epidemiological and case-control studies [reviewed in [85]]. One explanation is that people's memory of what they ate in a case-cohort study may have been tainted by their disease state. Another problem might be that the food frequency questionnaires (FFQ) used to measure food intake might not be accurate enough to detect differences. Such a problem was noted in the EPIC study at the Norfolk, UK site. Using a food diary the researchers found a significant correlation between saturated fat intake and breast cancer, but using a FFQ there was no significant correlation [86]. So, inaccurate measurement of fruit and vegetable intake might be part of the explanation as well.

It must be noted that upper intakes of fruits and vegetables in these studies are usually within the range of what people on an American omnivorous diet normally eat. In the Nurses Health Study the upper quintiles of fruit and vegetable intake were 4.5 and 6.2 servings/day, respectively [87]. Similarly, the upper quintiles of fruit and vegetable intake in the Health Professionals Followup Study were 4.3 and 5.4 serving/day for fruits and vegetables, respectively [87]. Intakes of fruits and vegetables on the Hallelujah Diet are much higher, with median reported intakes of six servings of fruits $(646 \mathrm{~g} /$ day $)$ and eleven servings of vegetables per day ( $971 \mathrm{~g} /$ day) [88] in addition to a green powder from the juice of barley leaves and alfalfa that is equivalent to approximately another $100 \mathrm{~g} /$ day of fresh dark greens. So, it is very possible that the range of intakes in the prospective population based studies do not have a wide enough intake on the upper end to detect the true possible impact of a very high intake of fruits and vegetables on cancer risk.

\section{Cruciferous Vegetables}

Cruciferous vegetables (broccoli, cauliflower, cabbage, Brussels sprouts) contain sulforophane, which has anti- 
cancer properties. A case-control study in China found that intake of cruciferous vegetables, measured by urinary secretion of isothiocyanates, was inversely related to the risk of breast cancer; the quartile with the highest intake only had $50 \%$ of the risk of the lowest intake group [89]. In the Nurses' Health Study a high intake of cruciferous vegetables ( 5 or more servings/week vs less than two servings/week) was associated with a 33\% lower risk of nonHodgkin's lymphoma [90]. In the Health Professionals Follow-up Study bladder cancer was only weakly associated with low intake of fruits and vegetables, but high intake ( 5 or more servings/week vs 1 or less servings/wk) of cruciferous vegetables was associated with a statistically significant $51 \%$ decrease in bladder cancer [91]. Also, prostate cancer risk was found to be reduced by cruciferous vegetable consumption in a population-based casecontrol study carried out in western Washington state. Three or more servings per week, compared to less than one serving of cruciferous vegetables per week resulted in a statistically significant $41 \%$ decrease in prostate cancer risk [92]. Similar protective effects of cruciferous vegetables were seen in a multi-ethnic case-control study [93]. A prospective study in Shanghai, China found that men with detectable amounts of isothiocyanates in their urine (metabolic products that come from cruciferous vegetables) had a 35\% decreased risk of lung cancer. Among men that had one or two genetic polymorphisms that caused them to eliminate these isothiocyanates slower there was a $64 \%$ or $72 \%$ decreased risk of lung cancer, respectively [94].

Broccoli sprouts have a very high concentration of sulforophane since this compound originates in the seed and is not made in the plant as it grows $[95,96]$. One sprout contains all of the sulforophane that is present in a full- grown broccoli plant. So, if sulforophane is especially cancer-protective, it would seem reasonable to include some broccoli sprouts in an anti-cancer diet.

\section{Selenium}

Selenium is a mineral with anti-cancer properties. Many studies in the last several years have shown that selenium is a potent protective nutrient for some forms of cancer. The Arizona Cancer Center posted a selenium fact sheet listing the major functions of selenium in the body [97]. These functions are as follows:

1. Selenium is present in the active site of many enzymes, including thioredoxin reductase, which catalyze oxidation-reduction reactions. These reactions may encourage cancerous cells to under apoptosis.

2. Selenium is a component of the antioxidant enzyme glutathione peroxidase.

3. Selenium improved the immune systems' ability to respond to infections.

4. Selenium causes the formation of natural killer cells.

5. P450 enzymes in the liver may be induced by selenium, leading to detoxification of some carcinogenic molecules.

6. Selenium inhibits prostaglandins that cause inflammation.

7. Selenium enhances male fertility by increased sperm motility.

8. Selenium can decrease the rate of tumor growth.

Table 2: Prospective Nested Case Control Studies of Selenium and Prostate Cancer.

\begin{tabular}{|c|c|c|c|c|c|}
\hline Reference & Study & \# Cases & \# Controls & Outcomes & Comment \\
\hline$[189]$ & $\begin{array}{l}\text { Physicians Health } \\
\text { Study }\end{array}$ & 586 & 577 & $\begin{array}{l}\uparrow \mathrm{Se}=\downarrow \text { risk of advance prostate cancer (OR } \\
=0.52,95 \% \mathrm{Cl}=0.28-0.98)\end{array}$ & $\begin{array}{l}\text { Result only in men with PSA } \geq 4 \mathrm{ng} / \\
\mathrm{mL}\end{array}$ \\
\hline$[190]$ & $\begin{array}{l}\text { Netherlands Cohort } \\
\text { Study }\end{array}$ & 540 & $|, 2| \mathrm{I}$ & $\begin{array}{l}\uparrow \mathrm{Se}=\downarrow \text { risk prostate cancer }(\mathrm{OR} \text { for quintiles } \\
\text { of } \mathrm{Se}=1.0,1.05,0.69,0.75,0.69 ; 95 \% \mathrm{Cl}= \\
0.48-0.99)\end{array}$ & Results greatest in ex-smokers \\
\hline$[191]$ & $\begin{array}{l}\text { Baltimore Longitudinal } \\
\text { Study of Aging }\end{array}$ & 52 & 96 & $\begin{array}{l}\uparrow \mathrm{Se}=\downarrow \text { risk prostate cancer (OR for quartiles } \\
\text { of } \mathrm{Se}=1.0,0.15,0.21,0.24\end{array}$ & \\
\hline$[192]$ & $\begin{array}{l}\text { Washington County, } \\
\text { Maryland }\end{array}$ & 117 & 233 & $\begin{array}{l}\text { Top } 4 / 5 \text { of Se had reduction in prostate } \\
\text { cancer risk; statistically significant result for } \\
\text { Se only when } \gamma \text { tocopherol levels were high }\end{array}$ & $\begin{array}{l}\text { Men in top quintile of serum } \\
\gamma \text { tocopherol had } 5 \text {-fold reduced risk } \\
\text { of prostate cancer compared to } \\
\text { lowest quintile }\end{array}$ \\
\hline$[193]$ & $\begin{array}{l}\text { Health Professional } \\
\text { Follow-up Study }\end{array}$ & 181 & $|8|$ & $\uparrow S e=\downarrow$ risk of advanced prostate cancer & $\begin{array}{l}\text { Adjusted OR }=0.35(95 \% \mathrm{Cl}= \\
0.16-0.78)\end{array}$ \\
\hline$[194]$ & Prospective study & & & $\begin{array}{l}\uparrow S e=\downarrow \text { risk of gastrointestinal and prostate } \\
\text { cancer }\end{array}$ & Results not statistically significant \\
\hline
\end{tabular}


A serendipitous randomized, double-blind, controlled trial of a $200 \mu \mathrm{g} /$ day selenium supplement in the southeastern region of the USA (where soil selenium levels are low) found that the primary endpoints of skin cancer were not improved by the selenium supplement, but that other cancer incidence rates were decreased by selenium $[98,99]$. There was a significant reduction in total cancer incidence (105 vs 137 cases, $\mathrm{P}=0.03$ ), prostate cancer (22 vs 42 cases, $\mathrm{P}=0.005)$, a marginally significant reduction in colorectal cancer incidence ( 9 vs 19 cases, $\mathrm{P}=0.057$ ), and a reduction in cancer mortality, all cancer sites (40 vs 66 deaths, $\mathrm{P}=0.008$ ) (selenium versus control group cases reported, respectively) [98]. The selenium supplement was most effective in ex-smokers and for those who began the study with the lowest levels of serum selenium. Several prospective studies have also examined the role of selenium in cancer prevention, particularly for prostate cancer, summarized in Table 2.

Overall, it appears that poor selenium levels, especially for men, are a cancer risk. If a person has low selenium levels and other antioxidant defenses are also low the cancer risk is increased even further. Women do not appear to be as sensitive to selenium, as breast cancer has not been found to be influenced by selenium status in several studies [100-104], although both men and women were found to be protected by higher levels of selenium from colon cancer [100] and lung cancer $[105,106]$. Good vegetarian sources of selenium are whole grains and legumes grown in selenium-rich soil in the western United States, brazil nuts (by far the most dense source of selenium), nutritional yeast, brewers yeast, and sunflower seeds.

\section{Chlorophyll}

All green plants also contain chlorophyll, the light-collecting molecule. Chlorophyll and its derivatives are very effective at binding polycyclic aromatic hydrocarbons (carcinogens largely from incomplete combustion of fuels), heterocyclic amines (generated when grilling foods), aflatoxin (a toxin from molds in foods which causes liver cancer), and other hydrophobic molecules. The chlorophyll-carcinogen complex is much harder for the body to absorb, so most of it is swept out with the feces. The chemoprotective effect of chlorophyll and its derivatives has been tested in laboratory cell cultures and animals $[107,108]$. There is so much compelling evidence for anti-carcinogenic effects of chlorophyll that a prospective randomized controlled trial is being conducted in Qidong, China to see if chlorophyllin can reduce the amount of liver cancer cases, which arise from aflatoxin exposure in their foods (corn, peanuts, soy sauce, and fermented soy beans). A 55\% reduction in aflatoxin-DNA adducts were found in the group that took $100 \mathrm{mg}$ of chlorophyllin three times a day [109]. It was supposed that the chlorophyllin bound up aflatoxins, but there were chlorophyllin derivatives also detected in the sera (which had a green tint to it) of the volunteers who took the supplement, indicating a possible role in the body besides binding carcinogens in the gut [110].

\section{Protective Vitamins \\ Vitamin B-12}

Vitamin B-12 has not been proven to be an anti-cancer agent, but there is some evidence indicating that it could be beneficial. The form of administered vitamin B-12 may be important.

Some experimental cancer studies have been carried out with various forms of vitamin B-12. Methylcobalamin inhibited tumor growth of SC-3 injected into mice [111], and caused SC-3 mouse mammary tumor cells to undergo apoptosis, even when stimulated to grow by the presence of growth-inducing androgen [112]. Methylcobalamin, but not cyanocobalamin, increased the survival time of mice bearing implanted leukemia tumor cells [113]. 5'deoxyadenosylcobalamin and methylcobalamin, but not cyanocobalamin, were shown to be effective cytotoxic agents [114]. Methylcobalamin also was able to increase survival time and reduce tumor growth in laboratory mice [115].

Laboratory mechanistic evidence for the effects of vitamin B12 were seen in a laboratory study with vitamin B-12 deficient rats. Choi et al [116] found that the colonic DNA of the B-12 deficient rats had a 35\% decrease in genomic methylation and a 105\% increase in uracil incorporation, both changes that could increase risk of carcinogenesis. In two prospective studies (one in Washington Country, Maryland and the Nurses' Health Study) a relation between lower vitamin B12 status (but not deficiency) and statistically significant higher risk of breast cancer was found $[117,118]$. So, there is evidence from laboratory studies, prospective cohort studies, and mechanistic studies showing that vitamin B-12 is an important nutrient for genetic stability, DNA repair, carcinogenesis, and cancer therapy.

\section{Folic Acid}

Folic acid is the dark green leafy vegetable vitamin. It has an integral role in DNA methylation and DNA synthesis. Folic acid works in conjunction with vitamin B-6 and vitamin B-12 in the single carbon methyl cycle. If insufficient folic acid is not available uracil is substituted for thymidine in DNA, which leads to DNA strand breakage. About $10 \%$ of the US population (and higher percentages among the poor) has low enough intakes of folic acid to make this a common problem [119]. As shown in Tables 3 and 4, many studies have found a significant reduction in colon, rectal, and breast cancer with higher intakes of folic acid and their related nutrients (vitamin B-6 and B- 
Table 3: Folate and Colon / Rectal Cancer.

\begin{tabular}{|c|c|c|c|c|c|}
\hline Reference & Study & \# Cases & \# Controls & Outcomes & Comment \\
\hline [195] & Case / control USA & 35 & 64 & $\begin{array}{l}\text { Folate supplementation }=62 \% \\
\text { lower incidence of neoplasia }\end{array}$ & result not SS \\
\hline [196] & $\begin{array}{l}\text { Case / control NY } \\
\text { state }\end{array}$ & 800 & $\begin{array}{l}\text { Matched neighbor- } \\
\text { hood controls }\end{array}$ & $\begin{array}{l}\uparrow \text { Folate }=\downarrow \text { rectal cancer, OR }= \\
0.5 \text { men, OR }=0.31, \text { women } \\
\text { Folate no effect for colon cancer }\end{array}$ & SS \\
\hline [197] & $\begin{array}{l}\text { Case / control } \\
\text { Majorca, Spain }\end{array}$ & 286 & 498 & $\begin{array}{l}\text { Colon cancer related to total } \\
\text { calories, cholesterol, animal } \\
\text { protein, low fiber, low folic acid }\end{array}$ & . \\
\hline [198] & $\begin{array}{l}\text { Case / Control Wash. } \\
\text { state }\end{array}$ & 424 & 414 & $\begin{array}{l}\uparrow \text { Alcohol }=\uparrow \text { cancer risk; } \uparrow \text { fiber }= \\
\downarrow \text { risk; no relation to folate intake }\end{array}$ & $\begin{array}{l}2.5 \mathrm{X} \text { risk for } 30 \mathrm{~g} / \mathrm{day} \\
\text { alcohol }\end{array}$ \\
\hline [199] & $\begin{array}{l}\text { Nurses' Health Study } \\
\text { \& Health Professionals } \\
\text { Follow-up Study }\end{array}$ & 564 women, 331 men & & $\begin{array}{l}\uparrow \text { folate }=\downarrow \text { risk of colorectal } \\
\text { adenoma: } O R_{\text {women }}=0.66, O R_{\text {men }} \\
=0.63\end{array}$ & \\
\hline [200] & Case / Control, Italy & 1,326 & $\begin{array}{l}2,024 \text { hospital } \\
\text { controls }\end{array}$ & $\begin{array}{l}\text { Protective trends for } \beta \text {-carotene, } \\
\text { ascorbic acid, vit } E \text {, and folate (OR } \\
=0.32,0.40,0.60,0.52 \text {, } \\
\text { respectively) }\end{array}$ & $\begin{array}{l}\text { Similar for colon and } \\
\text { rectal cancer }\end{array}$ \\
\hline [20I] & $\begin{array}{l}\text { US male health } \\
\text { professional cohort }\end{array}$ & 205 & & $\begin{array}{l}\uparrow \text { Alcohol }=\uparrow \text { colon cancer }(\mathrm{OR}= \\
2.07 \text { for } \geq 2 \text { drinks } / \text { day; folate } \\
\text { weakly protective; } \uparrow \text { Alcohol }+ \\
\downarrow \text { folate }=\uparrow \text { colon cancer risk (OR } \\
=3.30)\end{array}$ & \\
\hline [202] & $\begin{array}{l}\alpha \text {-tocopherol, } \beta \text { - } \\
\text { carotene study cohort } \\
\text { of smokers }\end{array}$ & 144 & 276 & $\begin{array}{l}\uparrow \text { dietary folate }=\downarrow \text { colon cancer } \\
(\mathrm{OR}=1.0,0.40,0.34,0.5 \mathrm{I}, \mathrm{P}- \\
\text { trend }=0.15)\end{array}$ & $\begin{array}{l}\text { alcohol intake } \\
\text { increased risk }\end{array}$ \\
\hline [203] & $\begin{array}{l}\text { Case control, } \\
\text { population based }\end{array}$ & & & $\begin{array}{l}\text { Composite dietary profile (alcohol } \\
\text { intake, methionine, folate, vit } B_{12} \text {, } \\
B_{6} \text { ) trend of increasing risk for } \\
\text { high risk group }\end{array}$ & Marginal SS \\
\hline [204] & Nurses' Health Study & 442 & & $\begin{array}{l}\uparrow \text { folate intake }=\downarrow \text { colon cancer } \\
(O R=0.69) \text {; long-term use of } \\
\text { multi-vitamins beneficial }\end{array}$ & $\begin{array}{l}\text { Folate intake includes } \\
\text { multi-vitamins }\end{array}$ \\
\hline [205] & $\begin{array}{l}\text { NYU Women's } \\
\text { Health Study }\end{array}$ & 105 & 523 & $\begin{array}{l}\uparrow \text { folate }=\downarrow \text { colorectal cancer risk } \\
(O R=0.52, P \text {-trend }=0.04\end{array}$ & Alcohol increased risk \\
\hline [206] & $\begin{array}{l}\text { NHANES I } \\
\text { Epidemiologic Follow- } \\
\text { up Study }\end{array}$ & & & $\begin{array}{l}\uparrow \text { folate }=\downarrow \text { colon cancer }\left(\mathrm{OR}_{\text {men }}=\right. \\
0.40, \mathrm{P} \text {-trend }=0.03 ; \uparrow \text { alcohol, } \\
\downarrow \text { folate }=\uparrow \text { colon cancer }\left(\mathrm{OR}_{\text {men }}=\right. \\
2.67\end{array}$ & $\begin{array}{l}\text { Results not stat. signif } \\
\text { in women }\end{array}$ \\
\hline [207] & Nurses' Health Study & 535 & & $\begin{array}{l}\uparrow \text { folate intake }=\downarrow \text { colon cancer in } \\
\text { women with family history (OR = } \\
0.48)\end{array}$ & $\begin{array}{l}\text { Folate effect greater in } \\
\text { women with family } \\
\text { history }\end{array}$ \\
\hline [208] & $\begin{array}{l}\text { Canadian National } \\
\text { Breast Screening } \\
\text { Study }\end{array}$ & 295 & 5,334 & $\begin{array}{l}\uparrow \text { folate }=\downarrow \text { colorectal cancer }(\mathrm{OR} \\
=0.6, \mathrm{P} \text {-trend }=0.25\end{array}$ & Results not SS \\
\hline [209] & $\begin{array}{l}\text { Prospective cohort in } \\
\text { The Netherlands }\end{array}$ & 1,171 & & $\begin{array}{l}\text { Rectal: OR, men } 0.66 \text {, women no } \\
\text { trend }\end{array}$ & Trends SS only in men \\
\hline$[210]$ & Case / Control Italy & 1,953 & 4,154 & $\begin{array}{l}\uparrow \text { folate }=\downarrow \text { colorectal cancer (OR } \\
=0.72)\end{array}$ & $\begin{array}{l}\text { Population drinks } \\
\text { alcohol regularly }\end{array}$ \\
\hline$[211]$ & $\begin{array}{l}\text { lowa Women's health } \\
\text { Study }\end{array}$ & 721 & & $\begin{array}{l}\uparrow \text { folate }+\left(\uparrow B_{12} \text { or } \uparrow B_{6}\right)=\downarrow \text { colon } \\
\text { cancer }(O R=0.59,0.65 \\
\text { respectively }\end{array}$ & $\begin{array}{l}\text { Nutrients not } \\
\text { independent, alcohol } \\
\text { increases risk }\end{array}$ \\
\hline$[2 \mid 2]$ & $\begin{array}{l}\text { Case / Control NC } \\
\text { state }\end{array}$ & 613 & 996 & $\begin{array}{l}\uparrow \beta \text {-carotene, vit } C \text {, calcium }=40- \\
60 \% \downarrow \text { risk colon cancer in whites; } \\
\text { in African Americans } \uparrow \text { vit } C \text { and } E \\
=50-70 \% \downarrow \text { risk colon cancer; no } \\
\text { relation to folate to cancer risk }\end{array}$ & $\begin{array}{l}\text { Colon cancer rates } \\
\text { higher in Aftrican } \\
\text { Americans in NC; due } \\
\text { to less UV light } \\
\text { absorption with dark } \\
\text { skin? }\end{array}$ \\
\hline [2।3] & $\begin{array}{l}\text { Wheat Bran Fiber } \\
\text { trial, test for } \\
\text { recurrence of } \\
\text { adenoma polyps }\end{array}$ & $\begin{array}{l}1,014 \text { men and } \\
\text { women }\end{array}$ & & $\begin{array}{l}\uparrow \text { homocysteine }=\uparrow \text { risk }(\mathrm{OR}= \\
0.69) ; \uparrow \text { plasma folate }=\downarrow_{\text {risk }}(\mathrm{OR} \\
=0.66) \uparrow \text { folate or } \mathrm{B}_{6} \text { intake }(\mathrm{diet}+ \\
\text { supplements) }=\downarrow_{\text {risk }}(\mathrm{OR}=0.6 \mathrm{I}\end{array}$ & $\begin{array}{l}\text { SS; cut-off for highest } \\
\text { quartile is } 664 \mu \mathrm{g} / \text { day } \\
\text { (way above RDA) }\end{array}$ \\
\hline
\end{tabular}

SS = statistically significant 
12). Alcohol is an antagonist of folate, so that drinking alcoholic beverages greatly magnifies the cancer risk of a low-folate diet. Genetic polymorphisms (common single DNA base mutations resulting in a different amino acid encoded into a protein) in the methylenetetrahydrofolate reductase and the methionine synthase genes which increase the relative amount of folate available for DNA synthesis and repair also reduces the risk of colon cancer [120-123]. Cravo et al [124] used $5 \mathrm{mg}$ of folic acid a day (a supraphysiological dose) in a prospective, controlled, cross-over study of 20 patients with colonic adenoma polyps. They found that the folic acid could reverse DNA hypomethylation in 7 of 12 patients who had only one polyp.

Folate may be more important for rapidly dividing tissue, like the colonic mucosa. Therefore, the cancer risk associated with low folate intake is probably higher for colon cancer than for breast cancer. Most of the breast cancer studies only found a protective effect of folate among women who consumed alcohol (see Table 4). However, among women residents of Shanghai who consumed no alcohol, no vitamin supplements and ate unprocessed, unfortified foods there was a $29 \%$ decreased risk of breast cancer among those with the highest intake of folate [125]. So, there may be a true protective effect that is masked in the western populations by so many other risk factors. Two studies showed that the risk of cancer due to family history can be modified by high folate intake, so a prudent anti-cancer diet would be high in dark green leafy vegetables. The mean intake of folic acid on the Hallelujah Diet was $594 \mu \mathrm{g} /$ day for men and $487 \mu \mathrm{g} /$ day for women [88].

\section{Vitamin D}

Vitamin D is produced primarily from the exposure of the skin to sunshine. Even casual exposure of the face, hands, and arms in the summer generates a large amount of vitamin D. In fact, simulated sunshine, equivalent to standing on a sunny beach until a slight pinkness of the skin was detected, was equivalent to a 20,000 IU oral dose of vitamin $D_{2}$ [126]. (Note that the RDA is $400 \mathrm{IU}$ for most adults.) It has been estimated that 1,000 IU per day is the minimal amount needed to maintain adequate levels of vitamin $\mathrm{D}$ in the absence of sunshine [126], and that up to 4,000 IU per day can be safely used with additional benefit [127].

The concentration of the active hormonal form of vitamin $\mathrm{D}$ is tightly regulated in the blood by the kidneys. This active hormonal form of vitamin $\mathrm{D}$ has the potent anticancer properties. It has been discovered that various types of normal and cancerous tissues, including prostate cells [128], colon tissue [129], breast, ovarian and cervical

Table 4: Prospective Studies of Folate and Breast Cancer.

\begin{tabular}{|c|c|c|c|c|c|}
\hline Reference & Study & \# Cases & \# Controls & Outcomes & Comment \\
\hline [2।4] & Nurses' Health Study & 3,483 & & $\begin{array}{l}\downarrow \text { folate intake }+ \text { alcohol }=\uparrow \text { risk of breast } \\
\text { cancer }(O R=0.55, P \text {-trend }=0.00 \mathrm{I})\end{array}$ & $\begin{array}{l}\text { Folate intake not associated } \\
\text { with overall risk of breast } \\
\text { cancer }\end{array}$ \\
\hline$[2 \mid 5]$ & $\begin{array}{l}\text { Canadian National Breast } \\
\text { Screening Study }\end{array}$ & 1,336 & 5,382 & $\begin{array}{l}\downarrow \text { folate intake }+ \text { alcohol }=\uparrow \text { risk of breast } \\
\text { cancer }(O R=0.34, P \text {-trend }=0.004)\end{array}$ & $\begin{array}{l}\text { Folate intake not associated } \\
\text { with overall risk of breast } \\
\text { cancer }\end{array}$ \\
\hline [216] & $\begin{array}{l}\text { Prospective study in USA } \\
\text { with postmenopausal } \\
\text { women }\end{array}$ & I,586 & & $\begin{array}{l}\text { Among drinkers, } \downarrow \text { folate intake }=\uparrow \text { breast } \\
\text { cancer risk }(O R=1.59)\end{array}$ & $\begin{array}{l}\text { No association in overall } \\
\text { cohort }\end{array}$ \\
\hline$[125]$ & $\begin{array}{l}\text { Shanghai Breast Cancer } \\
\text { Study, China }\end{array}$ & $|, 32|$ & 1,382 & $\begin{array}{l}\uparrow \text { folate intake }=\downarrow \text { risk }(\mathrm{OR}=0.7 \mathrm{I}, \mathrm{P}- \\
\text { trend }=0.05) ; \uparrow \text { folate, } \uparrow \text { methionine, } \uparrow \mathrm{B}_{6}, \\
\uparrow \mathrm{B}_{12}=\downarrow \text { risk }(\mathrm{OR}=0.47, \mathrm{P} \text {-trend }=0.0 \mathrm{I})\end{array}$ & $\begin{array}{l}\text { No alcohol, no supplements, } \\
\text { unprocessed, unfortified foods }\end{array}$ \\
\hline [2।7] & $\begin{array}{l}\text { Nurses' Health Study II, } \\
\text { study of premenopausal } \\
\text { women }\end{array}$ & $7 \mid 4$ & & $\begin{array}{l}\text { Vitamin A protective }(O R=0.28) \text {; } \\
\text { Vitamins } C, E \text {, and folate not associated } \\
\text { with risk. }\end{array}$ & \\
\hline$[118]$ & Nurses' Health Study & 712 & 712 matched & $\begin{array}{l}\uparrow \text { plasma folate }=\downarrow \text { risk }(\mathrm{OR}=0.73, \mathrm{P} \text { - } \\
\text { trend }=0.06) . \text { For women who drank } \\
\text { alcohol, } \uparrow \text { plasma folate even more } \\
\text { protective, OR }=0.1 \mathrm{I} .\end{array}$ & $\begin{array}{l}\uparrow \text { plasma } B_{6} \text { and plasma } B_{12} \\
\text { were also protective }\end{array}$ \\
\hline [2।8] & $\begin{array}{l}\text { Prospective study in USA } \\
\text { with postmenopausal } \\
\text { women }\end{array}$ & $\begin{array}{l}\text { I,823, } 308 \\
\text { with family } \\
\text { history }(\mathrm{FH})\end{array}$ & & $\begin{array}{l}\mathrm{FH}-+ \text { Alcohol }=\uparrow \text { risk }(\mathrm{OR}=\mathrm{I} .40) \mathrm{FH}-+ \\
\text { Alcohol }+\uparrow \text { folate }=\text { normal risk; } \mathrm{FH}+ \\
\downarrow \text { folate }=\uparrow \text { risk for drinkers }(\mathrm{OR}=2.2 \mathrm{I}) \\
\text { and non-drinkers }(\mathrm{OR}=2.39) ; \mathrm{FH}+ \\
+ \text { Alcohol }+\uparrow \text { folate }=\uparrow \text { risk }(\mathrm{OR}=\mathrm{I} .67) ; \\
\mathrm{FH}++\uparrow \text { folate }=\text { normal risk }\end{array}$ & $\begin{array}{l}\text { Women with family history of } \\
\text { breast cancer can reduce risk } \\
\text { by increasing folate intake and } \\
\text { not drinking. }\end{array}$ \\
\hline
\end{tabular}

$\mathrm{FH}=$ Family History 
tissue [130], pancreatic tissue [131] and a lung cancer cell line [132] all have the ability to convert the major circulating form of vitamin $\mathrm{D}, 25(\mathrm{OH}) \mathrm{D}$, into the active hormonal form, $1,25(\mathrm{OH})_{2} \mathrm{D}$. So, there is a local mechanism in many tissues of the body for converting the form of vitamin $\mathrm{D}$ in the body that is elevated by sunshine exposure into a hormone that has anticancer activity.

Indeed, 25(OH)D has been shown to inhibit growth of colonic epithelial cells [133], primary prostatic epithelial cells [134], and pancreatic cells [131]. So, the laboratory work is confirming what had been seen some time ago in ecological studies of populations and sunshine exposure.

The mortality rates for colon, breast, and ovary cancer in the USA show a marked north-south gradient [135]. In ecological studies of populations and sunlight exposure (no individual data) sunlight has been found to have a protective effect for prostate cancer [136], ovarian cancer [137], and breast cancer [138]. Recently Grant found that sunlight was also protective for bladder, endometrial, renal cancer, multiple myeloma, and Non-Hodgkins lymphoma in Europe [139] and bladder, esophageal, kidney, lung, pancreatic, rectal, stomach, and corpus uteri cancer in the USA [140]. Several prospective studies of vitamin D and cancer have also shown a protective effect of vitamin D (see Table 5). It could be that sunshine and vitamin D are protective factors for cancers of many organs that can convert 25(OH)D into $1,25(\mathrm{OH}) \mathrm{D}_{2}$.

\section{Antioxidants}

$\alpha$ - and $\beta$-Carotene and other Carotenoids

Carotenoids have been studied vigorously to see if these colorful compounds can decrease cancer risk. In ecological studies and early case-control studies it appeared that $\beta$-carotene was a cancer-protective agent. Randomized controlled trials of $\beta$-carotene found that the isolated nutrient was either neutral [141] or actually increased risk of lung cancer in smokers $[142,143]$. Beta-carotene may be a marker for intake of fruits and vegetables, but it does not have a powerful protective effect in isolated pharmacological doses.

Table 5: Prospective Studies of Vitamin D and Cancer.

\begin{tabular}{|c|c|c|c|c|c|c|}
\hline Reference & Study & Vit D measure & \# Cases & \# Controls & Outcomes & Comment \\
\hline$[219]$ & $\begin{array}{l}\text { 19-year cohort study } \\
\text { of } 1,954 \text { men }\end{array}$ & Diet history & & & $\begin{array}{l}\uparrow \text { vit } D+\text { calcium }=\downarrow \text { colorectal } \\
\text { cancer (rates for lowest to } \\
\text { highest intakes were } 38.9,24,5 \text {, } \\
22,5 \text { and } 14.3 / 1000 \text { population }\end{array}$ & $\begin{array}{l}\text { Significant effect even } \\
\text { after adjustments for } \\
\text { confounding factors; } 2.7 \\
\text { fold reduction. }\end{array}$ \\
\hline$[220]$ & $\begin{array}{l}\text { Washington county, } \\
\text { Maryland cohort }\end{array}$ & Serum $25(\mathrm{OH}) \mathrm{D}$ & 34 & 67 matched & $\begin{array}{l}\uparrow \text { serum vit } D=\downarrow \text { colon cancer. } \\
\text { Relative risk was } 0.25 \text { for } 3^{\text {rd }} \\
\text { quintile and } 0.20 \text { for } 4^{\text {th }} \text { quintile. }\end{array}$ & 4-5 fold reduction \\
\hline$[221]$ & $\begin{array}{l}\text { Physicians' Health } \\
\text { Study }\end{array}$ & $\begin{array}{l}\text { Serum } 25(\mathrm{OH}) \mathrm{D} \& \\
\mathrm{I}, 25(\mathrm{OH}) \mathrm{D}_{2}\end{array}$ & 232 & 414 & $\begin{array}{l}\text { No relation between vitamin D } \\
\text { metabolite levels and prostate } \\
\text { cancer }\end{array}$ & \\
\hline$[222]$ & Nurses' Health Study & $\begin{array}{l}\text { Dietary and } \\
\text { supplement intake }\end{array}$ & & & $\begin{array}{l}\text { Colon cancer } \mathrm{RR}=0.42 \text { (SS) } \\
\text { for total vitamin } \mathrm{D} \text {, comparing } \\
\text { top and bottom quintiles }\end{array}$ & $\begin{array}{l}\text { Calcium not related to } \\
\text { colon cancer risks; } 2.4 \\
\text { fold reduction }\end{array}$ \\
\hline$[223]$ & Finnish clinical cohort & $\begin{array}{l}\text { Serum } 25(\mathrm{OH}) \mathrm{D} \& \\
\mathrm{I}, 25(\mathrm{OH}) \mathrm{D}_{2}\end{array}$ & 146 & 292 & $\begin{array}{l}\uparrow \text { serum } 25(\mathrm{OH}) \mathrm{D}=\downarrow \text { risk of } \\
\text { rectal cancer, RR by quartile }= \\
\mathrm{I} .00,0.93,0.77,0.37, \mathrm{P} \text { trend }= \\
0.06 .\end{array}$ & $\begin{array}{l}\text { Serum } 25(\mathrm{OH}) \mathrm{D} 12 \% \\
\text { lower in cases than in } \\
\text { controls }(12.2 \text { vs } 13.8 \\
\text { ng/l, } \mathrm{P}=0.0 \mathrm{I} ; 2.7 \text {-fold } \\
\text { reduction }\end{array}$ \\
\hline$[224]$ & $\begin{array}{l}\text { NHANES I Follow-up } \\
\text { Study }\end{array}$ & Sunlight and diet & $\begin{array}{l}190 \\
\text { women }\end{array}$ & Cohort matched & $\begin{array}{l}\text { Risk reductions for breast } \\
\text { cancer for women in regions } \\
\text { with high solar radiation (RR } \\
0.35-0.75 \text { ). }\end{array}$ & \\
\hline$[225]$ & Helsinki Heart Study & Serum $25(\mathrm{OH}) \mathrm{D}$ & 149 & 596 & $\begin{array}{l}\uparrow \text { serum } 25(\mathrm{OH}) \mathrm{D}=\downarrow \text { prostate } \\
\text { cancer. } 1.7 \text { fold greater risk for } \\
\text { below median level compared } \\
\text { to above median level. }\end{array}$ & $\begin{array}{l}\text { Young men }(<52 \text { years } \\
\text { old) with low } 25(\mathrm{OH}) \mathrm{D} \\
\text { had much higher risk of } \\
\text { advanced prostate } \\
\text { cancer }(\mathrm{OR}=6.3)\end{array}$ \\
\hline$[226]$ & $\begin{array}{l}\text { Randomized } \\
\text { controlled trial for } \\
\text { colon adenoma } \\
\text { recurrence }\end{array}$ & $\begin{array}{l}\text { Serum } 25(\mathrm{OH}) \mathrm{D} \text { \& } \\
\mathrm{I}, 25(\mathrm{OH}) \mathrm{D}_{2}, \text { and } \\
\text { supplementary } \\
\text { calcium }\end{array}$ & $\begin{array}{l}803 \\
\text { subjects } \\
\text { total }\end{array}$ & & $\begin{array}{l}\text { Above medium } 25(\mathrm{OH}) \mathrm{D} \text { and } \\
\text { supplemental calcium reduced } \\
\text { adenoma recurrence }(\mathrm{RR}= \\
0.7 \mathrm{I})\end{array}$ & $\begin{array}{l}\text { Calcium and vitamin D } \\
\text { appeared to work } \\
\text { together to reduce } \\
\text { colon cancer risk. }\end{array}$ \\
\hline$[227]$ & $\begin{array}{l}\text { Norway, Finland, } \\
\text { Sweden cohort of } \\
\text { men }\end{array}$ & Serum $25(\mathrm{OH}) \mathrm{D}$ & 622 & $1,45 \mid$ & $\begin{array}{l}\leq 19 \mathrm{nmol} / \mathrm{l} \text { and } \geq 80 \mathrm{nmol} / \mathrm{l} \text { of } \\
25(\mathrm{OH}) \mathrm{D} \text { at higher risk of } \\
\text { prostate cancer. ( } 40-60 \mathrm{nmol} / \mathrm{l} \\
\text { had lowest risk). }\end{array}$ & \\
\hline
\end{tabular}


However, there is a large body of literature that indicates that dietary carotenoids are cancer preventative (See Table 6 ). Alpha-carotene has been found to be a stronger protective agent than its well-known isomer $\beta$-carotene. Studies tend to agree that overall intake of carotenoids is more protective than a high intake of a single carotenoid. So, a variety of fruits and vegetables is still a better anti-cancer strategy than just using a single vegetable high in a specific carotenoid.

The richest source of $\alpha$-carotene is carrots and carrot juice, with pumpkins and winter squash as a second most-dense source. There is approximately one $\mu \mathrm{g}$ of $\alpha$-carotene for every two $\mu$ g of $\beta$-carotene in carrots. The most common sources of $\beta$-cryptoxanthin are citrus fruits and red sweet peppers.

\section{Lycopene}

Of the various carotenoids lycopene has been found to be very protective, particularly for prostate cancer. The major dietary source of lycopene is tomatoes, with the lycopene in cooked tomatoes being more bioavailable than that in raw tomatoes. Several prospective cohort studies have found associations between high intake of lycopene and reduced incidence of prostate cancer, though not all studies have produced consistent results [144,145]. Some studies suffer from a lack of good correlation between lycopene intake assessed by questionnaire and actual serum levels, and other studies measured intakes among a population that consumed very few tomato products. The studies with positive results will be reviewed here.

Table 6: Studies of Carotenoids and Lung Cancer.

\begin{tabular}{|c|c|c|c|c|c|}
\hline Reference & Study & \# Cases & \# Controls & Outcomes & Comment \\
\hline [228] & Hawaiian cohort & 332 & 865 & $\begin{array}{l}\text { Dose-dependent inverse associations for } \\
\text { dietary } \beta \text {-carotene, } \alpha \text {-carotene, lutein; } \\
\text { Subjects with highest intake of all } 3 \text { had the } \\
\text { lowest risk }\end{array}$ & $\begin{array}{l}\text { Previous study showed variety of } \\
\text { vegetables more protective than } \\
\text { just foods rich in a particular } \\
\text { carotenoid }\end{array}$ \\
\hline [229] & $\begin{array}{l}\text { Washington county, } \\
\text { Maryland residents }\end{array}$ & 258 & 515 & $\begin{array}{l}\uparrow \text { Serum} / \text { plasma levels of cryptoxanthin, } \beta \text { - } \\
\text { carotene, lutein/zeaxanthin }=\downarrow \text { cancer }(\mathrm{OR}= \\
0.74,0.83,0.90, \mathrm{SS})\end{array}$ & \\
\hline [230] & Case control, Spain & 103 & 206, hospital & $\begin{array}{l}\text { No association for intake of } \alpha \text {-carotene, } \beta \text { - } \\
\text { carotene, or lutein. }\end{array}$ & \\
\hline [23I] & Case control, Uruguay & 541 & 540 & $\uparrow$ total carotenoids $=\downarrow$ cancer $(\mathrm{OR}=0.43, \mathrm{SS})$ & $\begin{array}{l}\text { Risk reduction for vit } \mathrm{E} \text { and } \\
\text { glutathione also seen. }\end{array}$ \\
\hline \multirow[t]{2}{*}{ [232] } & Finland cohort & 138 & & $\begin{array}{l}\uparrow \alpha \text {-carotene }=\downarrow \text { cancer }(\mathrm{OR}=0.6 \mathrm{I}, \mathrm{SS}) ; \beta \text { - } \\
\text { carotene inversely related but not SS. }\end{array}$ & $90 \%$ of $\alpha$-carotene from carrots \\
\hline & & & & & $\begin{array}{l}\uparrow \text { Fruits and } \uparrow \text { root vegetables }= \\
\downarrow \text { cancer }(\mathrm{OR}=0.58,0.56, \\
\text { respectively, SS) }\end{array}$ \\
\hline [233] & $\begin{array}{l}\text { Nurses' Health Study } \\
\& \text { Health Professionals } \\
\text { Follow-Up Study }\end{array}$ & 794 & & $\begin{array}{l}\uparrow \alpha \text {-carotene, lycopene, total carotenoids }= \\
\downarrow \text { cancer }(\mathrm{OR}=0.75,0.80,068 \text { respectively, } \\
\text { SS); Never smokers }+\uparrow \alpha \text {-carotene }=\downarrow \text { cancer } \\
(\mathrm{OR}=0.37, \mathrm{SS})\end{array}$ & $\begin{array}{l}4-8 \text { year lag between diet } \\
\text { assessment and date of diagnosis } \\
\text { gave strongest correlations. }\end{array}$ \\
\hline [234] & Shanghai men's cohort & 209 & 622 & $\begin{array}{l}\uparrow \text { serum } \beta \text {-cryptoxanthin }=\downarrow \text { cancer }(O R \\
\text { quartiles }=1,0.72,0.42,0.45, \text { P-trend }=0.02) \text {; } \\
\text { Smokers with above median level of total } \\
\text { carotenoids had a SS } 37 \% \text { reduction in cancer } \\
\text { risk }\end{array}$ & $\begin{array}{l}\text { Study population had } \sim 50 \% \text { lower } \\
\text { mean levels of serum carotenoids } \\
\text { compared to US whites. }\end{array}$ \\
\hline [235] & $\begin{array}{l}\text { Canadian National } \\
\text { Breast Screening } \\
\text { Study }\end{array}$ & 155 & 5,631 & $\begin{array}{l}\text { Non-significant inverse trend in risk for } \alpha \text { - } \\
\text { carotene and } \beta \text {-cryptoxanthin }\end{array}$ & $\begin{array}{l}\beta \text {-cryptoxanthin most from citrus, } \\
\text { red peppers }\end{array}$ \\
\hline [236] & $\begin{array}{l}\text { Japan Collaborative } \\
\text { Cohort Study }\end{array}$ & 147 & 311 & $\begin{array}{l}\uparrow \alpha \text {-carotene, } \beta \text {-carotene, canthaxanthin, total } \\
\text { carotenoids }=\downarrow \text { risk }(\mathrm{OR}=0.35,0.2 \mathrm{I}, 0.37, \\
0.27 \text { respectively, SS); lycopene and } \beta- \\
\text { cryptoxanthin reduce lung cancer risk, but } \\
\text { not significantly }\end{array}$ & \\
\hline [237] & $\begin{array}{l}\text { Singapore Chinese } \\
\text { Health Study }\end{array}$ & 482 & & $\begin{array}{l}\uparrow \text { dietary } \beta \text {-cryptoxanthin }=\downarrow \text { cancer risk (OR } \\
=0.73,0.63 \text { for smokers, } S S)\end{array}$ & $\begin{array}{l}\text { No significant associations of other } \\
\text { carotenoids with lung cancer }\end{array}$ \\
\hline [238] & $\begin{array}{l}\text { Pooled analysis of } 7 \\
\text { cohorts in USA and } \\
\text { Europe }\end{array}$ & 3,155 & & $\begin{array}{l}\uparrow \text { dietary } \beta \text {-cryptoxanthin }=\downarrow \text { lung cancer }(\mathrm{OR} \\
=0.76, \mathrm{SS})\end{array}$ & $\begin{array}{l}\text { Other dietary carotenoids not } \\
\text { significantly related to lung cancer. }\end{array}$ \\
\hline
\end{tabular}

SS = statistically significant difference between comparison groups. 
In the Health Professionals Follow-up Study there was a $21 \%$ decrease in prostate cancer risk, comparing the highest quintile of lycopene intake with the lowest quintile. Combined intake of tomatoes, tomato sauce, tomato juice, and pizza (which accounted for $82 \%$ of the lycopene intake) were associated with a $35 \%$ lower risk of prostate cancer. Furthermore, lycopene was even more protective for advanced stages of prostate cancer, with a $53 \%$ decrease in risk [146]. A more recent follow-up report on this same cohort of men confirmed these original findings that lycopene or frequent tomato intake is associated with about a $30-40 \%$ decrease in risk of prostate cancer, especially advanced prostate cancer [147].

In addition to the two reports above a nested case control study from the Health Professional Follow-up Study with 450 cases and controls found an inverse relation between plasma lycopene and prostate cancer risk (OR 0.48) among older subjects ( $>65$ years of age) without a family history of prostate cancer [148]. Among younger men high plasma $\beta$-carotene was associated with a statistically significant $64 \%$ decrease in prostate cancer risk. So, the results for lycopene have been found for dietary intakes as well as plasma levels.

In a nested case-control study from the Physicians' Health Study cohort, a placebo-controlled study of aspirin and $\beta$ carotene, there was a $60 \%$ reduction in advanced prostate cancer risk ( $P$-trend $=0.006$ ) for those subjects in the placebo group with the highest plasma lycopene levels, compared to the lowest quintile. The $\beta$-carotene also had a protective effect, especially for those men with low lycopene levels [149].

In addition to these observational studies, two clinical trials have been conducted to supplement lycopene for a short period before radical prostatectomy. In one study 30 $\mathrm{mg} /$ day of lycopene were given to 15 men in the intervention group while the 11 men were in the control group were instructed to follow the National Cancer Institute's recommendations to consume at least 5 servings of fruits and vegetables daily. Results showed that the lycopene slowed the growth of prostate cancer. Prostate tissue lycopene concentration was $47 \%$ higher in the intervention group. Subjects that took the lycopene for 3 weeks had smaller tumors, less involvement of the surgical margins, and less diffuse involvement of the prostate by pre-cancerous high-grade prostatic intraepithelial neoplasia [150]. In another study before radical prostatectomy surgery 32 men were given a tomato sauce-based pasta dish every day, which supplied $30 \mathrm{mg}$ of lycopene per day. After 3 weeks serum and prostate lycopene levels increaed 2-fold and 2.9-fold, respectively. PSA levels decreased 17\%, as seen also by Kucuk et al [150]. Oxidative DNA damage was $21 \%$ lower in subjects' leukocytes and $28 \%$ lower in prostate tissue, compared to non-study controls. The apoptotic index was 3-fold higher in the resected prostate tissue, compared to biopsy tissue [151]. These intervention studies raise the question of what could have been done in this intervention was longer and combined synergistically with other effective intervention methods, such as flax seed, increased selenium and possibly vitamin E, in the context of a diet high in fruits and vegetable?

\section{Vitamin C}

Vitamin C, or ascorbic acid, has been studied in relation to health and is the most common supplement taken in the USA. Low blood levels of ascorbic acid are detrimental to health (for a recent article see Fletcher et al [152]) and vitamin $\mathrm{C}$ is correlated with overall good health and cancer prevention [153]. Use of vitamin C for cancer therapy was popularized by Linus Pauling. At high concentrations ascorbate is preferentially toxic to cancer cells. There is some evidence that large doses of vitamin $\mathrm{C}$, either in multiple divided oral doses or intravenously, have beneficial effects in cancer therapy [154-156]. Oral doses, even in multiple divided doses, are not as effective as intravenous administration. Vitamin $\mathrm{C}$ at a dose of $1.25 \mathrm{~g}$ administered orally produced mean peak plasma concentrations of $135 \pm 21 \mu \mathrm{mol} / \mathrm{L}$ compared with $885 \pm 201 \mu \mathrm{mol} / \mathrm{L}$ for intravenous administration [154].

While vitamin $\mathrm{C}$ is quite possibly an effective substance, the amounts required for these therapeutic effects are obviously beyond dietary intakes. However, intravenous ascorbate may be a very beneficial adjuvant therapy for cancer with no negative side effects when administered properly.

\section{Other Antioxidants}

There are many more substances that will have some benefit for cancer therapy. Most of these substances are found in foods, but their effective doses for therapy are much higher than the normal concentration in the food. For example, grape seed extract contains proanthocyanidin, which shows anticarcinogenic properties (reviewed by Cos et al \[157]. Also, green tea contains a flavanol, epigallocatechin-3-gallate (EGCG), which can inhibit metalloproteinases, among several possible other mechanisms [158]. And there are claims for various other herbal substances and extracts that might be of benefit, which are beyond the scope of this review.

\section{Probiotics}

The bacteria that reside in the intestinal tract generally have a symbiotic relationship with their host. Beneficial bacteria produce natural antibiotics to keep pathogenic bugs in check (preventing diarrhea and infections) and produce some B vitamins in the small intestine where they can be utilized. Beneficial bacteria help with food diges- 
tion by providing extra enzymes, such as lactase, in the small intestine. Beneficial bacteria help strengthen the immune system right in the gut where much of the interaction between the outside world and the body goes on. Beneficial bacteria can help prevent food allergies. They can help prevent cancer at various stages of development. These good bacteria can improve mineral absorption, maximizing food utilization.

However, the balance of beneficial and potentially pathogenic bacteria in the gut is dependent on the diet. Vegetable fiber encourages the growth of beneficial bacteria. A group of Adventist vegetarians was found to have a higher amount of beneficial bacteria and lower amount of potentially pathogenic bacteria compared to non-vegetarians on a conventional American diet [159]. Differences in bacterial populations were seen between patients who recently had a colon polyp removed, Japanese-Hawaiians, North American Caucasians, native rural Japanese, and rural native Africans. Lactobacillus species and Eubacterium aerofaciens, both producers of lactic acid, were associated with the populations with the lower risk of colon cancer, while Bacteroides and Bifidobacterium species were associated with higher risk of colon cancer [160]

There is a solid theoretical basis for why probiotics should help prevent cancer, especially colon cancer, and even reverse cancer. Probiotics produce short chain fatty acids in the colon, which acidify the environment. Lower colon $\mathrm{pH}$ is associated with lower incidence of colon cancer. Probiotic bacteria reduce the level of procarcinogenic enzymes such as beta-glucuronidase, nitroreductase, and azoreductase [161].

L. casei was used in two trials of patients with superficial bladder cancer. In the first trial, the probiotic group had a $50 \%$ disease free time of 350 days, compared to 195 days for the control group [162]. The second trial also showed that the probiotics worked better than the placebo, except for multiple recurring tumors [163].

Except for the two studies noted above, most of the research of probiotics and cancer has been done in animals. Studies have looked at markers of tumor growth or at animals with chemically induced tumors.

Studies in rats have shown that probiotics can inhibit the formation of aberrant crypt foci, thought to be a pre-cancerous lesion in the colon. Some of the best results were obtained with a probiotic strain consumed with inulin, a type of fructooligosaccharide. Total aberrant crypt foci, chemically induced, were reduced $74 \%$ by the treatment of rats with inulin and B. longum, but only 29 and $21 \%$ by B. longum and inulin alone, respectively [164]. There was a synergistic effect in using both products together. Simi- lar synergy was seen in rats with azoxymethane-induced colon cancer in another study. Rats fed Raftilose, a mixture of inulin and oligofructose, or Raftilose with Lactobacilli rhamnosus (LGG) and Bifidobacterium lactis (Bb12) had a significantly lower number of tumors compared to the control group [165]. A probiotic mixture, without any prebiotic, given to rats fed azoxymethane reduced colon tumors compared to the control (50\% vs 90\%), and also reduced the number of tumors per tumor-bearing rat [166].

In lab mice bred to be susceptible to colitis and colon cancer, a probiotic supplement, Lactobacillus salivarium ssp. Salivarius UCC118, reduced fecal coliform levels, the number of potentially pathogenic Clostridium perfringens, and reduced intestinal inflammation. In this small study two mice died of fulminant colitis and 5 mice developed adenocarcinoma in the control group of 10 mice, while there was no colitis and only 1 mouse with adenocarcinoma in the probiotic test group [167].

The research on probiotics and disease is still an emerging field. There is a high degree of variation of health benefits between different strains of bacteria. As new methods for selecting and screening probiotics become available, the field will be able to advance more rapidly.

\section{Oral Enzymes}

Many people diagnosed with cancer have digestion or intestinal tract disorders as well. Impaired digestion will greatly hinder a nutritional approach to treating cancer. If the nutrients cannot be released from the food and taken up by the body, then the excellent food provided by the Hallelujah Diet will go to waste. Digestive enzyme supplements are used to ensure proper and adequate digestion of food. Even raw foods, which contain many digestive enzymes to assist in their digestion, will be more thoroughly digested with less of the body's own resources with the use of digestive enzymes. So, the enzymes taken with meals do not have a direct effect upon a tumor, but assist the body in getting all of the nutrition out of the food for healing and restoring the body to normal function. Recently, an in vitro system was used to test the use of supplemental digestive enzymes. The digestive enzymes improved the digestibility and bioaccessibility of proteins and carbohydrates in the lumen of the small intestine, not only under impaired digestive conditions, but also in healthy human digestion [168].

There is evidence that indicates the presence of an enteropancreatic circulation of digestive enzymes [169]. Digestive enzymes appear to be preferentially absorbed into the bloodstream and then reaccumulated by the pancreas for use again. There appears to be a mechanism by which digestive enzymes can reach systemic circulation. 
Enzymes, especially proteases, if they reach systemic circulation, can have direct anti-tumor activity. Wald et al [170] reported on the anti-metastatic effect of enzyme supplements. Mice inoculated with the Lewis lung carcinoma were treated with a proteolytic enzyme supplement, given rectally (to avoid digestion). The primary tumor was cut out, so that the metastatic spread of the cancer could be measured. After surgical removal of the primary tumor (day 0 ), $90 \%$ of the control mice died by day 18 due to metastasized tumors. In the first group, which received the rectal enzyme supplement from the time of the tumorremoval surgery, $30 \%$ of the mice had died from metastasized cancer by day 25. In the second group, which received the enzymes from 6 days prior to removal of the primary tumor, only $10 \%$ of the animals showed the metastatic process by day 15 . In the third group, which received the enzyme treatment since the initial inoculation of the Lewis lung carcinoma, no metastatic spread of the tumor was discernible. One hundred day-survival rates for the control, first, second, and third groups were $0,60 \%, 90 \%$, and $100 \%$.

In a similar experiment, an enzyme mixture of papain, trypsin, and chymotrypsin, as used in the preparation Wobe-Mugos E, was rectally given to mice that were inoculated with melanoma cells. Survival time was prolonged in the test group ( 38 days in the enzyme group compared to 24 days in the control mice) and 3 of the 10 enzymesupplemented mice were cured. Again, a strong anti-metastatic effect of the proteolytic enzymes was seen [171].

Further evidence of the efficacy of oral enzyme supplementation is available from clinical trials in Europe. Two different studies have demonstrated that two different oral proteolytic enzyme supplements were able to reduce high levels of transforming growth factor- $\beta$, which may be a factor in some cancers $[172,173]$. In the Slovak Republic an oral enzyme supplement was tested in a placebo-controlled trial of multiple myeloma. For stage III multiple myeloma, control group survival was 47 months, compared to 83 months (a 3 year gain) for patients who took the oral enzymes for more than 6 months [174].

Enzyme supplements have also been shown to reduce side effects of cancer therapy. Enzyme supplementation resulted in fewer side effects for women undergoing radiation therapy for carcinomas of the uterine cervix [175], for patients undergoing radiation therapy for head and neck cancers [176], and for colorectal cancer patients undergoing conventional cancer treatments [177]. In a large multi-site study in Germany women undergoing conventional cancer therapy were put into a control group or a group that received an oral enzyme supplement. Disease and therapy related symptoms were all reduced, except tumor pain, by the enzyme supplement. Also, sur- vival was longer with less recurrence and less metastases in the enzyme group [178]. In all of these studies the oral enzyme supplements were well tolerated, with only a small amount of mild to moderate gastrointestinal symptoms.

Even though these few studies don't give a lot of evidence of the effectiveness of oral enzyme supplementation, it is clear that there are some circumstances that will be helped by enzyme supplementation, with very little danger of negative side effects. At the least, enzymes will improve digestion and lessen the digestive burden on the body, leaving more reserves for disease eradication. However, as the research indicates, the effect may be much greater than that, with the potential for direct anti-tumor activity.

\section{Whole Diet Studies}

A diet-based cancer therapy, the Gerson Therapy, was used to treat melanoma cancer. The five-year survival rates from their therapy compared very favorably to conventional therapy reported in the medical literature, especially for more advanced stages of melanoma [179] (see Table 7).

Table 7: Gerson Therapy for Melanoma [179].

\begin{tabular}{lll}
\hline Stage of melanoma & Gerson & Historical controls \\
\hline I- II & $100 \%(\mathrm{~N}=14)$ & $79 \%(\mathrm{~N}=15,798)$ \\
IIIA & $82 \%(\mathrm{~N}=17)$ & $39 \%(\mathrm{~N}=103)$ \\
IIIA + IIIB & $70 \%(\mathrm{~N}=33)$ & $41 \%(\mathrm{~N}=130)$ \\
IVA & $39 \%(\mathrm{~N}=18)$ & $6 \%(\mathrm{~N}=194)$ \\
\hline
\end{tabular}

An Italian cohort of 8,984 women was followed for an average of 9.5 years, with 207 incident cases of breast cancer during that time. Their diets were analyzed by patterns - salad vegetables (raw vegetables and olive oil), western (potatoes, red meat, eggs and butter), canteen (pasta and tomato sauce), and prudent (cooked vegetables, pulses, and fish). Only the salad vegetable diet pattern was associated with a significantly lower risk of breast cancer, about 35\% lower. For women of normal weight (BMI <25) the salad vegetable pattern was even more protective, about a $61 \%$ decreased risk of breast cancer [180]. The overall dietary pattern does make a very significant difference.

In US-based studies the "prudent" diet has been shown to be protective for colon cancer, while the "western" diet has been shown to be detrimental. The "western" dietary pattern, with its higher intakes of red meat and processed meats, sweets and desserts, French fries, and refined grains, was associated with a $46 \%$ increase relative risk of 
colon cancer in the Nurses' Health Study [45]. Slattery et al [17] found a two-fold increase in relative risk of colon cancer associated with a "western" dietary pattern, and a $35-40 \%$ decrease in relative risk associated with the "prudent" pattern, especially among those diagnosed at an earlier age ( $<67$ years old). The "salad vegetable" pattern is still more likely to be protective compared to the prudent dietary pattern, but this pattern did not exist in this study population.

In an analysis of the colon cancer data from the Health Professionals Follow-up Study, Platz et al [56] found that there was a $71 \%$ decrease in colon cancer risk when men with none of six established risk factors were compared to men with at least one of these risk factors (obesity, physical inactivity, alcohol consumption, early adulthood cigarette smoking, red meat consumption, and low intake of folic acid from supplements). So, if all men had the same health profile as these healthier $3 \%$ of the study population, colon cancer rates would have been only $29 \%$ of what they measured.

A plant-based dietary pattern in being currently tested in the Women's healthy Eating and Living (WHEL) Study. About 3,000 women who were treated for an early stage of breast cancer have been randomized into two groups. The dietary goals for the test group of the study are 5 servings of vegetables, $16 \mathrm{oz}$ of vegetable juice, 3 servings of fruit, $30 \mathrm{~g}$ of fiber, and $<20 \%$ of energy from fat. No guidelines were given for animal product intake, and initial results seem to confirm, since there were no changes in body weight, total cholesterol, or LDL cholesterol [181], which would be affected by animal protein intake. However, over the first year of follow-up vegetable intake did increase to seven servings/day, fruit intake increased to 3.9 servings/day, energy from fat decreased from $28 \%$ to $23 \%$. Also, plasma carotenoid concentrations increased significantly in the intervention group, but not in the control group. $\alpha$-Carotene increased 223\%, $\beta$-carotene increased $87 \%$, lutein increase $29 \%$, and lycopene increased $17 \%$ [182], indicating that a substantial dietary change had been made by these women. It will be very interesting to follow the results of this study.

\section{Conclusions}

What is the result when all of these things are put together? What if all of these factors reviewed here were taken into account and put into practice? This anticancer diet would have:

- adequate, but not excessive calories,

- 10 or more servings of vegetables a day, including cruciferous and allium vegetables; vegetable juice could meet part of this goal,
- 4 or more servings of fruits a day,

- high in fiber,

- no refined sugar,

- no refined flour,

- low in total fat, but containing necessary essential fatty acids,

- no red meat,

- a balanced ratio of omega 3 and omega 6 fats and would include DHA,

- flax seed as a source of phytoestrogens,

- supplemented with 200 $\mu \mathrm{g} /$ day selenium,

- supplemented with 1,000 $\mu \mathrm{g} /$ day methylcobalamin (B12),

- very rich in folic acid (from dark green vegetables),

- adequate sunshine to get vitamin D, or use 1,000 IU/day supplement,

- very rich in antioxidants and phytochemicals from fruits and vegetables, including $\alpha$-carotene, $\beta$-carotene, $\beta$-cryptoxanthin, vitamin C (from foods), vitamin E (from foods),

- very rich in chlorophyll,

- supplemented with beneficial probiotics,

- supplemented with oral enzymes

As reviewed above, reductions of 60 percent in breast cancer rates have already been seen in human diet studies, and a 71 percent reduction in colon cancer for men without the known modifiable risk factors. These reductions are without taking into account many of the other factors considered in this review, such as markedly increased fruit and vegetable intake, balanced omega 3 and 6 fats, vitamin $D$, reduced sugar intake, probiotics, and enzymes factors which all are likely to have an impact on cancer. Certainly cancer prevention would be possible, and cancer reversal in some cases is quite likely.

\section{Competing Interests}

Michael Donaldson is a research scientist at the Hallelujah Acres Foundation, a foundation for investigations pertain- 
ing to the Hallelujah Diet. Funding for this review was provided by the Hallelujah Acres Foundation.

\section{References}

I. WCRF/AICR: Food, nutrition and the prevention of cancer: a global perspective:. World Cancer Research Fund / American Institute for Cancer Research 1997.

2. Vastag B: Obesity Is Now on Everyone's Plate. Jama 2004, 291:।186-1188.

3. Sturm R: Increases in clinically severe obesity in the United States, I 986-2000. Arch Intern Med 2003, I 63:2146-2| 48.

4. Mokdad AH, Marks JS, Stroup DF, Gerberding JL: Actual causes of death in the United States, 2000. Jama 2004, 29 I: I 238-I 245.

5. Calle EE, Rodriguez C, Walker-Thurmond K, Thun MJ: Overweight, obesity, and mortality from cancer in a prospectively studied cohort of U.S. adults. N Engl J Med 2003, 348: I625-1638.

6. Hursting SD, Lavigne JA, Berrigan D, Perkins SN, Barrett JC: Calorie restriction, aging, and cancer prevention: mechanisms of action and applicability to humans. Annu Rev Med 2003, 54:|3|-|52. Epub 200| Dec 2003.

7. Dirx MJ, Zeegers MP, Dagnelie PC, van den Bogaard T, van den Brandt PA: Energy restriction and the risk of spontaneous mammary tumors in mice: a meta-analysis. Int J Cancer 2003, I 06:766-770.

8. Harvell DM, Strecker TE, Xie B, Pennington KL, McComb RD, Shull JD: Dietary energy restriction inhibits estrogen-induced mammary, but not pituitary, tumorigenesis in the $A C l$ rat. Carcinogenesis 2002, 23:161-169.

9. Matsuzaki J, Yamaji R, Kiyomiya K, Kurebe M, Inui H, Nakano Y: Implanted tumor growth is suppressed and survival is prolonged in sixty percent of food-restricted mice. J Nutr 2000, I30: III-II5.

10. Michels $\mathrm{KB}$, Ekbom A: Caloric restriction and incidence of breast cancer. Jama 2004, 29 I: | 226-| 230.

II. Foster-Powell K, Holt SH, Brand-Miller JC: International table of glycemic index and glycemic load values: 2002. Am J Clin Nutr 2002, 76:5-56

12. Augustin LS, Gallus S, Negri E, La Vecchia C: Glycemic index, glycemic load and risk of gastric cancer. Ann Oncol 2004, I 5:58|-584.

13. Augustin LS, Gallus S, Franceschi S, Negri E, Jenkins DJ, Kendall CW, Dal Maso L, Talamini R, La Vecchia C: Glycemic index and load and risk of upper aero-digestive tract neoplasms (Italy). Cancer Causes Control 2003, 14:657-662.

14. Augustin LS, Gallus S, Bosetti C, Levi F, Negri E, Franceschi S, Dal Maso L, Jenkins DJ, Kendall CW, La Vecchia C: Glycemic index and glycemic load in endometrial cancer. Int J Cancer 2003, 105:404-407.

15. Augustin LS, Polesel J, Bosetti C, Kendall CW, La Vecchia C, Parpinel M, Conti E, Montella M, Franceschi S, Jenkins DJ, Dal Maso L: Dietary glycemic index, glycemic load and ovarian cancer risk: a case-control study in Italy. Ann Oncol 2003, I 4:78-84.

16. Franceschi S, Dal Maso L, Augustin L, Negri E, Parpinel M, Boyle P, Jenkins DJ, La Vecchia C: Dietary glycemic load and colorectal cancer risk. Ann Oncol 200I, I 2:173-I78.

17. Slattery ML, Boucher KM, Caan BJ, Potter JD, Ma KN: Eating patterns and risk of colon cancer. Am J Epidemiol 1998, I48:4-I6.

18. Bostick RM, Potter JD, Kushi LH, Sellers TA, Steinmetz KA, McKenzie DR, Gapstur SM, Folsom AR: Sugar, meat, and fat intake, and non-dietary risk factors for colon cancer incidence in lowa women (United States). Cancer Causes Control 1994, 5:38-52.

19. Frazier AL, Li L, Cho E, Willett WC, Colditz GA: Adolescent diet and risk of breast cancer. Cancer Causes Control 2004, I 5:73-82.

20. Higginbotham S, Zhang ZF, Lee IM, Cook NR, Giovannucci E, Buring JE, Liu S: Dietary glycemic load and risk of colorectal cancer in the Women's Health Study. I Natl Cancer Inst 2004, 96:229-233.

21. Cho E, Spiegelman D, Hunter DJ, Chen WY, Colditz GA, Willett WC Premenopausal dietary carbohydrate, glycemic index, glycemic load, and fiber in relation to risk of breast cancer. Cancer Epidemiol Biomarkers Prev 2003, I 2: I |53-1 I 58.

22. Folsom AR, Demissie Z, Harnack L: Glycemic index, glycemic load, and incidence of endometrial cancer: the lowa women's health study. Nutr Cancer 2003, 46: I I9- 124.
23. Higginbotham S, Zhang ZF, Lee IM, Cook NR, Buring JE, Liu S: Dietary glycemic load and breast cancer risk in the Women's Health Study. Cancer Epidemiol Biomarkers Prev 2004, I 3:65-70.

24. Michaud DS, Liu S, Giovannucci E, Willett WC, Colditz GA, Fuchs CS: Dietary sugar, glycemic load, and pancreatic cancer risk in a prospective study. J Natl Cancer Inst 2002, 94: I 293-I300.

25. Holmes MD, Liu S, Hankinson SE, Colditz GA, Hunter DJ, Willett WC: Dietary carbohydrates, fiber, and breast cancer risk. Am J Epidemiol 2004, I 59:732-739.

26. Jonas CR, McCullough ML, Teras LR, Walker-Thurmond KA, Thun $M J$, Calle EE: Dietary glycemic index, glycemic load, and risk of incident breast cancer in postmenopausal women. Cancer Epidemiol Biomarkers Prev 2003, I 2:573-577.

27. Oh K, Willett WC, Fuchs CS, Giovannucci EL: Glycemic index, glycemic load, and carbohydrate intake in relation to risk of distal colorectal adenoma in women. Cancer Epidemiol Biomarkers Prev 2004, 13: $1192-1198$.

28. Terry PD, Jain M, Miller AB, Howe GR, Rohan TE: Glycemic load, carbohydrate intake, and risk of colorectal cancer in women: a prospective cohort study. I Natl Cancer Inst 2003, 95:9|4-916.

29. Hu FB, Manson JE, Liu S, Hunter D, Colditz GA, Michels KB, Speizer $\mathrm{FE}$, Giovannucci E: Prospective study of adult onset diabetes mellitus (type 2) and risk of colorectal cancer in women. Natl Cancer lnst 1999, 9 I:542-547.

30. Khaw KT, Wareham N, Bingham S, Luben R, Welch A, Day N: Preliminary communication: glycated hemoglobin, diabetes, and incident colorectal cancer in men and women: a prospective analysis from the European prospective investigation into cancer-Norfolk study. Cancer Epidemiol Biomarkers Prev 2004, 13:915-919.

31. Saydah SH, Platz EA, Rifai N, Pollak MN, Brancati FL, Helzlsouer KJ: Association of markers of insulin and glucose control with subsequent colorectal cancer risk. Cancer Epidemiol Biomarkers Prev 2003, 12:412-418.

32. Platz EA, Hankinson SE, Rifai N, Colditz GA, Speizer FE, Giovannucci $\mathrm{E}$ : Glycosylated hemoglobin and risk of colorectal cancer and adenoma (United States). Cancer Causes Control 1999, I 0:379-386.

33. Schoen RE, Tangen CM, Kuller LH, Burke GL, Cushman M, Tracy RP, Dobs A, Savage PJ: Increased blood glucose and insulin, body size, and incident colorectal cancer. J Natl Cancer Inst 1999, 91:। |47-II54.

34. Colangelo LA, Gapstur SM, Gann PH, Dyer AR, Liu K: Colorectal cancer mortality and factors related to the insulin resistance syndrome. Cancer Epidemiol Biomarkers Prev 2002, I I:385-391.

35. Coughlin SS, Calle EE, Teras LR, Petrelli J, Thun MJ: Diabetes mellitus as a predictor of cancer mortality in a large cohort of US adults. Am J Epidemiol 2004, I 59: I I60-I I 67.

36. La Vecchia C, Negri E, Decarli A, Franceschi S: Diabetes mellitus and colorectal cancer risk. Cancer Epidemiol Biomarkers Prev 1997, 6:1007-1010

37. Sandhu MS, Luben R, Khaw KT: Self reported non-insulin dependent diabetes, family history, and risk of prevalent colorectal cancer: population based, cross sectional study. J Epidemiol Community Health 200I, 55:804-805.

38. Anderson KE, Anderson E, Mink PJ, Hong CP, Kushi LH, Sellers TA Lazovich D, Folsom AR: Diabetes and endometrial cancer in the lowa women's health study. Cancer Epidemiol Biomarkers Prev 200I, I0:6II-6I6.

39. Calle EE, Murphy TK, Rodriguez C, Thun MJ, Heath CW Jr: Diabetes mellitus and pancreatic cancer mortality in a prospective cohort of United States adults. Cancer Causes Control 1998, 9:403-4I0.

40. Slattery ML, Curtin KP, Edwards SL, Schaffer DM: Plant foods, fiber, and rectal cancer. Am J Clin Nutr 2004, 79:274-28I.

4I. Bingham SA, Hughes R, Cross AJ: Effect of white versus red meat on endogenous $\mathbf{N}$-nitrosation in the human colon and further evidence of a dose response. J Nutr 2002, I32:3522S-3525S.

42. Chen J, Stampfer MJ, Hough HL, Garcia-Closas M, Willett WC, Hennekens $\mathrm{CH}$, Kelsey $\mathrm{KT}$, Hunter DJ: A prospective study of $\mathbf{N}$ acetyltransferase genotype, red meat intake, and risk of colorectal cancer. Cancer Res 1998, 58:3307-33 II.

43. Fernandez E, La Vecchia C, D'Avanzo B, Negri E, Franceschi S: Risk factors for colorectal cancer in subjects with family history of the disease. Br J Cancer 1997, 75:1381-1384. 
44. Franceschi S, Favero A, La Vecchia C, Negri E, Conti E, Montella M, Giacosa A, Nanni O, Decarli A: Food groups and risk of colorectal cancer in Italy. Int J Cancer 1997, 72:56-6I.

45. Fung T, Hu FB, Fuchs C, Giovannucci E, Hunter DJ, Stampfer MJ, Colditz GA, Willett WC: Major dietary patterns and the risk of colorectal cancer in women. Arch Intern Med 2003, 163:309-314.

46. Giovannucci E, Stampfer MJ, Colditz G, Rimm EB, Willett WC: Relationship of diet to risk of colorectal adenoma in men. J Natl Cancer lnst 1992, 84:91-98.

47. Giovannucci E, Rimm EB, Stampfer MJ, Colditz GA, Ascherio A, Willett WC: Intake of fat, meat, and fiber in relation to risk of colon cancer in men. Cancer Res 1994, 54:2390-2397.

48. Hsing AW, McLaughlin JK, Chow WH, Schuman LM, Co Chien HT, Gridley G, Bjelke E, Wacholder S, Blot WJ: Risk factors for colorectal cancer in a prospective study among U.S. white men. Int J Cancer 1998, 77:549-553.

49. Hughes R, Pollock JR, Bingham S: Effect of vegetables, tea, and soy on endogenous $\mathbf{N}$-nitrosation, fecal ammonia, and fecal water genotoxicity during a high red meat diet in humans. Nutr Cancer 2002, 42:70-77.

50. Kampman E, Verhoeven D, Sloots L, van 't Veer P: Vegetable and animal products as determinants of colon cancer risk in Dutch men and women. Cancer Causes Control 1995, 6:225-234.

51. Kampman E, Slattery ML, Bigler J, Leppert M, Samowitz W, Caan BJ, Potter JD: Meat consumption, genetic susceptibility, and colon cancer risk: a United States multicenter case-control study. Cancer Epidemiol Biomarkers Prev 1999, 8: I5-24.

52. Kato I, Akhmedkhanov A, Koenig K, Toniolo PG, Shore RE, Riboli E: Prospective study of diet and female colorectal cancer: the New York University Women's Health Study. Nutr Cancer 1997, 28:276-28I.

53. La Vecchia C, Chatenoud L, Altieri A, Tavani A: Nutrition and health: epidemiology of diet, cancer and cardiovascular disease in Italy. Nutr Metab Cardiovasc Dis 200 I, I I:I0-15.

54. Le Marchand L, Donlon T, Seifried A, Wilkens LR: Red meat intake, CYP2EI genetic polymorphisms, and colorectal cancer risk. Cancer Epidemiol Biomarkers Prev 2002, I I : I019-1024.

55. Levi F, Pasche C, La Vecchia C, Lucchini F, Franceschi S: Food groups and colorectal cancer risk. $\mathrm{Br} J$ Cancer 1999, 79: $1283-1287$

56. Platz EA, Willett WC, Colditz GA, Rimm EB, Spiegelman D, Giovannucci E: Proportion of colon cancer risk that might be preventable in a cohort of middle-aged US men. Cancer Causes Control 2000, I I:579-588.

57. Seow A, Quah SR, Nyam D, Straughan PT, Chua T, Aw TC: Food groups and the risk of colorectal carcinoma in an Asian population. Cancer 2002, 95:2390-2396

58. Silvester KR, Bingham SA, Pollock JR, Cummings JH, O'Neill IK: Effect of meat and resistant starch on fecal excretion of apparent $\mathbf{N}$-nitroso compounds and ammonia from the human large bowel. Nutr Cancer 1997, 29:13-23.

59. Singh PN, Fraser GE: Dietary risk factors for colon cancer in a low-risk population. Am J Epidemiol 1998, 148:76I-774.

60. Sinha R, Chow WH, Kulldorff M, Denobile J, Butler J, Garcia-Closas $M$, Weil R, Hoover RN, Rothman N: Well-done, grilled red meat increases the risk of colorectal adenomas. Cancer Res 1999, 59:4320-4324

61. Slattery ML, Curtin K, Ma K, Edwards S, Schaffer D, Anderson K, Samowitz W: Diet activity, and lifestyle associations with p53 mutations in colon tumors. Cancer Epidemiol Biomarkers Prev 2002, I I:54 |-548.

62. Thun MJ, Calle EE, Namboodiri MM, Flanders WD, Coates RJ, Byers T, Boffetta P, Garfinkel L, Heath CW Jr: Risk factors for fatal colon cancer in a large prospective study. I Natl Cancer Inst 1992, 84: $149 \mid-1500$

63. Tiemersma EW, Kampman E, Bueno de Mesquita HB, Bunschoten A, van Schothorst EM, Kok FJ, Kromhout D: Meat consumption, cigarette smoking, and genetic susceptibility in the etiology of colorectal cancer: results from a Dutch prospective study. Cancer Causes Control 2002, I 3:383-393.

64. Willett WC, Stampfer MJ, Colditz GA, Rosner BA, Speizer FE: Relation of meat, fat, and fiber intake to the risk of colon cancer in a prospective study among women. N Engl J Med 1990, 323:1664-1672.
65. Norat T, Lukanova A, Ferrari P, Riboli E: Meat consumption and colorectal cancer risk: dose-response meta-analysis of epidemiological studies. Int J Cancer 2002, 98:24I-256.

66. De Stefani E, Ronco A, Mendilaharsu M, Guidobono M, Deneo-Pellegrini $\mathrm{H}$ : Meat intake, heterocyclic amines, and risk of breast cancer: a case-control study in Uruguay. Cancer Epidemiol Biomarkers Prev 1997, 6:573-58I.

67. London SJ, Sacks FM, Stampfer MJ, Henderson IC, Maclure M, Tomita A, Wood WC, Remine S, Robert NJ, Dmochowski JR: Fatty acid composition of the subcutaneous adipose tissue and risk of proliferative benign breast disease and breast cancer. J Nat Cancer Inst 1993, 85:785-793.

68. Bernard-Gallon DJ, Vissac-Sabatier C, Antoine-Vincent D, Rio PG, Maurizis JC, Fustier P, Bignon YJ: Differential effects of $\mathbf{n - 3}$ and $\mathbf{n -}$ 6 polyunsaturated fatty acids on BRCAI and BRCA2 gene expression in breast cell lines. Br J Nutr 2002, 87:28I-289.

69. Brooks JD, Ward WE, Lewis JE, Hilditch J, Nickell L, Wong E, Thompson LU: Supplementation with flaxseed alters estrogen metabolism in postmenopausal women to a greater extent than does supplementation with an equal amount of soy. $\mathrm{Am}$ J Clin Nutr 2004, 79:3 I8-325

70. Thompson LU, Rickard SE, Orcheson LJ, SeidI MM: Flaxseed and its lignan and oil components reduce mammary tumor growth at a late stage of carcinogenesis. Carcinogenesis 1996, I 7:1373-1376.

7I. Thompson LU, Seidl MM, Rickard SE, Orcheson LJ, Fong HH: Antitumorigenic effect of a mammalian lignan precursor from flaxseed. Nutr Cancer 1996, 26:159-165.

72. Yan L, Yee JA, Li D, McGuire MH, Thompson LU: Dietary flaxseed supplementation and experimental metastasis of melanoma cells in mice. Cancer Lett 1998, I24:181-186.

73. Li D, Yee JA, Thompson LU, Yan L: Dietary supplementation with secoisolariciresinol diglycoside (SDG) reduces experimental metastasis of melanoma cells in mice. Cancer Lett 1999 , 142:91-96.

74. Chen J, Stavro PM, Thompson LU: Dietary flaxseed inhibits human breast cancer growth and metastasis and downregulates expression of insulin-like growth factor and epidermal growth factor receptor. Nutr Cancer 2002, 43: 187-192.

75. Tan KP, Chen J, Ward WE, Thompson LU: Mammary gland morphogenesis is enhanced by exposure to flaxseed or its major lignan during suckling in rats. Exp Biol Med (Maywood) 2004, 229:147-157.

76. Chen J, Tan KP, Ward WE, Thompson LU: Exposure to flaxseed or its purified lignan during suckling inhibits chemically induced rat mammary tumorigenesis. Exp Biol Med (Maywood) 2003, 228:95 I-958

77. Lin X, Gingrich JR, Bao W, Li J, Haroon ZA, Demark-Wahnefried W: Effect of flaxseed supplementation on prostatic carcinoma in transgenic mice. Urology 2002, 60:919-924.

78. Demark-Wahnefried W, Price DT, Polascik TJ, Robertson CN, Anderson EE, Paulson DF, Walther PJ, Gannon M, Vollmer RT: Pilot study of dietary fat restriction and flaxseed supplementation in men with prostate cancer before surgery: exploring the effects on hormonal levels, prostate-specific antigen, and histopathologic features. Urology 200I, 58:47-52.

79. Brouwer IA, Katan MB, Zock PL: Dietary alpha-linolenic acid is associated with reduced risk of fatal coronary heart disease, but increased prostate cancer risk: a meta-analysis. J Nutr 2004, 134:919-922

80. Block G, Patterson B, Subar A: Fruit, vegetables, and cancer prevention: a review of the epidemiological evidence. Nutr Cancer 1992, 1 8: 1-29.

8I. Steinmetz KA, Potter JD: Vegetables, fruit, and cancer prevention: a review. J Am Diet Assoc 1996, 96:1027-1039.

82. Fleischauer AT, Poole C, Arab L: Garlic consumption and cancer prevention: meta-analyses of colorectal and stomach cancers. Am J Clin Nutr 2000, 72:1047-1052.

83. Fleischauer AT, Arab L: Garlic and cancer: a critical review of the epidemiologic literature. I Nutr 200 I, I 3 I : I 032S- I040S.

84. Hsing AW, Chokkalingam AP, Gao YT, Madigan MP, Deng J, Gridley $G$, Fraumeni JF Jr: Allium vegetables and risk of prostate cancer: a population-based study. I Natl Cancer Inst 2002, 94: $|648-| 65 \mid$. 
85. Riboli E, Norat T: Epidemiologic evidence of the protective effect of fruit and vegetables on cancer risk. Am J Clin Nutr 2003, 78:559S-569S.

86. Bingham SA, Luben R, Welch A, Wareham N, Khaw KT, Day N: Are imprecise methods obscuring a relation between fat and breast cancer? Lancet 2003, 362:212-214.

87. Joshipura KJ, Ascherio A, Manson JE, Stampfer MJ, Rimm EB, Speizer FE, Hennekens CH, Spiegelman D, Willett WC: Fruit and vegetable intake in relation to risk of ischemic stroke. Jama 1999, 282: 1233-1239.

88. Donaldson MS: Food and nutrient intake of Hallelujah vegetarians. Nutrition \& Food Science 200I, 3 I:293-303.

89. Fowke JH, Chung FL, Jin F, Qi D, Cai Q, Conaway C, Cheng JR, Shu $X O$, Gao YT, Zheng W: Urinary isothiocyanate levels, brassica, and human breast cancer. Cancer Res 2003, 63:3980-3986.

90. Zhang SM, Hunter DJ, Rosner BA, Giovannucci EL, Colditz GA, Speizer FE, Willett WC: Intakes of fruits, vegetables, and related nutrients and the risk of non-Hodgkin's lymphoma among women. Cancer Epidemiol Biomarkers Prev 2000, 9:477-485.

91. Michaud DS, Spiegelman D, Clinton SK, Rimm EB, Willett WC, Giovannucci EL: Fruit and vegetable intake and incidence of bladder cancer in a male prospective cohort. J Natl Cancer Inst 1999, 9l:605-613.

92. Cohen JH, Kristal AR, Stanford JL: Fruit and vegetable intakes and prostate cancer risk. J Natl Cancer Inst 2000, 92:6I-68.

93. Kolonel LN, Hankin JH, Whittemore AS, Wu AH, Gallagher RP, Wilkens LR, John EM, Howe GR, Dreon DM, West DW, Paffenbarger RS Jr: Vegetables, fruits, legumes and prostate cancer: a multiethnic case-control study. Cancer Epidemiol Biomarkers Prev 2000, 9:795-804

94. London SJ, Yuan JM, Chung FL, Gao YT, Coetzee GA, Ross RK, Yu MC: Isothiocyanates, glutathione S-transferase MI and $\mathrm{TI}$ polymorphisms, and lung-cancer risk: a prospective study of men in Shanghai, China. Lancet 2000, 356:724-729.

95. Fahey JW, Zhang Y, Talalay P: Broccoli sprouts: an exceptionally rich source of inducers of enzymes that protect against chemical carcinogens. Proc Natl Acad Sci U S A 1997. 94:10367-10372.

96. Shapiro TA, Fahey JW, Wade KL, Stephenson KK, Talalay P: Chemoprotective glucosinolates and isothiocyanates of broccoli sprouts: metabolism and excretion in humans. Cancer Epidemiol Biomarkers Prev 200I, 10:50I-508.

97. Selenium Information Sheet [http://www.selenium.arizona.edu/ INFOse.htm]

98. Duffield-Lillico AJ, Reid ME, Turnbull BW, Combs GF Jr, Slate EH, Fischbach LA, Marshall JR, Clark LC: Baseline characteristics and the effect of selenium supplementation on cancer incidence in a randomized clinical trial: a summary report of the Nutritional Prevention of Cancer Trial. Cancer Epidemiol Biomarkers Prev 2002, I I:630-639.

99. Clark LC, Combs GF Jr, Turnbull BW, Slate EH, Chalker DK, Chow J, Davis LS, Glover RA, Graham GF, Gross EG, Krongrad A, Lesher JL $J r$, Park HK, Sanders BB Jr, Smith CL, Taylor JR: Effects of selenium supplementation for cancer prevention in patients with carcinoma of the skin. A randomized controlled trial. Nutritional Prevention of Cancer Study Group. Jama 1996, 276: 1957-1963.

100. Ghadirian P, Maisonneuve P, Perret C, Kennedy G, Boyle P, Krewski $D$, Lacroix $A$ : $A$ case-control study of toenail selenium and cancer of the breast, colon, and prostate. Cancer Detect Prev 2000, 24:305-313.

10I. van den Brandt PA, Goldbohm RA, van't Veer P, Bode P, Dorant E, Hermus RJ, Sturmans F: Toenail selenium levels and the risk of breast cancer. Am J Epidemiol 1994, 140:20-26.

102. Hunter DJ, Morris JS, Stampfer MJ, Colditz GA, Speizer FE, Willett WC: A prospective study of selenium status and breast cancer risk. Jama 1990, 264: | |28-I| |3|.

103. van 't Veer P, van der Wielen RP, Kok FJ, Hermus RJ, Sturmans F: Selenium in diet, blood, and toenails in relation to breast cancer: a case-control study. Am J Epidemiol 1990, I 3 I:987-994.

104. van Noord PA, Collette HJ, Maas MJ, de Waard F: Selenium levels in nails of premenopausal breast cancer patients assessed prediagnostically in a cohort-nested case-referent study among women screened in the DOM project. Int J Epidemiol 1987, 16:318-322
105. Reid ME, Duffield-Lillico AJ, Garland L, Turnbull BW, Clark LC, Marshall JR: Selenium supplementation and lung cancer incidence: an update of the nutritional prevention of cancer trial. Cancer Epidemiol Biomarkers Prev 2002, I I: | 285- I29 I.

106. van den Brandt PA, Goldbohm RA, van 't Veer P, Bode P, Dorant E, Hermus RJ, Sturmans F: A prospective cohort study on selenium status and the risk of lung cancer. Cancer Res 1993, 53:4860-4865.

107. Chernomorsky S, Segelman A, Poretz RD: Effect of dietary chlorophyll derivatives on mutagenesis and tumor cell growth. Teratog Carcinog Mutagen 1999, 19:3 I 3-322.

108. Sarkar D, Sharma A, Talukder G: Chlorophyll and chlorophyllin as modifiers of genotoxic effects. Mutat Res 1994, 3 I 8:239-247.

109. Egner PA, Wang JB, Zhu YR, Zhang BC, Wu Y, Zhang QN, Qian GS, Kuang SY, Gange SJ, Jacobson LP, Helzlsouer KJ, Bailey GS, Groopman JD, Kensler TW: Chlorophyllin intervention reduces aflatoxin-DNA adducts in individuals at high risk for liver cancer. Proc Natl Acad Sci U S A 200I, 98: I460 I- I 4606.

1 10. Egner PA, Stansbury KH, Snyder EP, Rogers ME, Hintz PA, Kensler TW: Identification and characterization of chlorin e(4) ethyl ester in sera of individuals participating in the chlorophyllin chemoprevention trial. Chem Res Toxicol 2000, 13:900-906.

III. Nishizawa Y, Yamamoto T, Terada N, Fushiki S, Matsumoto K: Effects of methylcobalamin on the proliferation of androgensensitive or estrogen-sensitive malignant cells in culture and in vivo. Int I Vitam Nutr Res 1997, 67:164-170.

1 12. Nishizawa Y, Goto HG, Tanigaki Y, Fushiki S: Induction of apoptosis in an androgen-dependent mouse mammary carcinoma cell line by methylcobalamin. Anticancer Res 200 I, 2 I: I I07-I I I0.

113. Tsao CS, Myashita K: Influence of cobalamin on the survival of mice bearing ascites tumor. Pathobiology 1993, 61:104-108.

II4. Tsao CS, Miyashita K, Young M: Cytotoxic activity of cobalamin in cultured malignant and nonmalignant cells. Pathobiology 1990, 58:292-296.

I 15. Shimizu N, Hamazoe R, Kanayama H, Maeta M, Koga S: Experimental study of antitumor effect of methyl-B I2. Oncology I987, 44:169-173.

I16. Choi SW, Friso S, Ghandour H, Bagley PJ, Selhub J, Mason JB: Vitamin B-12 deficiency induces anomalies of base substitution and methylation in the DNA of rat colonic epithelium. J Nutr 2004, 134:750-755.

1 17. Wu K, Helzlsouer KJ, Comstock GW, Hoffman SC, Nadeau MR, Selhub J: A prospective study on folate, BI2, and pyridoxal $5^{\prime}$ phosphate (B6) and breast cancer. Cancer Epidemiol Biomarkers Prev 1999, 8:209-217.

I 8. Zhang SM, Willett WC, Selhub J, Hunter DJ, Giovannucci EL, Holmes MD, Colditz GA, Hankinson SE: Plasma folate, vitamin B6, vitamin B I 2, homocysteine, and risk of breast cancer. I Natl Cancer Inst 2003, 95:373-380.

119. Blount BC, Mack MM, Wehr CM, MacGregor JT, Hiatt RA, Wang G, Wickramasinghe SN, Everson RB, Ames BN: Folate deficiency causes uracil misincorporation into human DNA and chromosome breakage: implications for cancer and neuronal damage. Proc Natl Acad Sci U S A 1997, 94:3290-3295.

120. Ma J, Stampfer MJ, Giovannucci E, Artigas C, Hunter DJ, Fuchs C, Willett WC, Selhub J, Hennekens CH, Rozen R: Methylenetetrahydrofolate reductase polymorphism, dietary interactions, and risk of colorectal cancer. Cancer Res 1997, 57:1098-I I02.

12I. Ma J, Stampfer MJ, Christensen B, Giovannucci E, Hunter DJ, Chen J, Willett WC, Selhub J, Hennekens CH, Gravel R, Rozen R: A polymorphism of the methionine synthase gene: association with plasma folate, vitamin BI2, homocyst(e)ine, and colorectal cancer risk. Cancer Epidemiol Biomarkers Prev 1999, 8:825-829.

122. Giovannucci E, Chen J, Smith-Warner SA, Rimm EB, Fuchs CS, Palomeque C, Willett WC, Hunter DJ: Methylenetetrahydrofolate reductase, alcohol dehydrogenase, diet, and risk of colorectal adenomas. Cancer Epidemiol Biomarkers Prev 2003, 12:970-979.

123. Le Marchand L, Donlon T, Hankin JH, Kolonel LN, Wilkens LR, Seifried A: B-vitamin intake, metabolic genes, and colorectal cancer risk (United States). Cancer Causes Control 2002, 13:239-248

124. Cravo ML, Pinto AG, Chaves P, Cruz JA, Lage P, Nobre Leitao C, Costa Mira F: Effect of folate supplementation on DNA methylation of rectal mucosa in patients with colonic adenomas: correlation with nutrient intake. Clin Nutr 1998, 17:45-49. 
125. Shrubsole MJ, Jin F, Dai Q, Shu XO, Potter JD, Hebert JR, Gao YT, Zheng W: Dietary folate intake and breast cancer risk: results from the Shanghai Breast Cancer Study. Cancer Res 200I, 6I:7|36-7|4I.

126. Holick MF: Vitamin D: importance in the prevention of cancers, type I diabetes, heart disease, and osteoporosis. Am J Clin Nutr 2004, 79:362-37I.

127. Vieth R, Kimball S, Hu A, Walfish PG: Randomized comparison of the effects of the vitamin D3 adequate intake versus $100 \mathrm{mcg}$ (4000 IU) per day on biochemical responses and the wellbeing of patients. Nutr J 2004, 3:8.

128. Schwartz GG, Whitlatch LW, Chen TC, Lokeshwar BL, Holick MF: Human prostate cells synthesize I,25-dihydroxyvitamin D3 from 25-hydroxyvitamin D3. Cancer Epidemiol Biomarkers Prev 1998, 7:39|-395.

129. Tangpricha V, Flanagan JN, Whitlatch LW, Tseng CC, Chen TC, Holt PR, Lipkin MS, Holick MF: 25-hydroxyvitamin D-I alpha-hydroxylase in normal and malignant colon tissue. Lancet 200I, 357:1673-1674.

130. Friedrich M, Rafi L, Mitschele T, Tilgen W, Schmidt W, Reichrath J: Analysis of the vitamin $D$ system in cervical carcinomas, breast cancer and ovarian cancer. Recent Results Cancer Res 2003 1 64:239-246.

131. Schwartz GG, Eads D, Rao A, Cramer SD, Willingham MC, Chen TC, Jamieson DP, Wang L, Burnstein KL, Holick MF, Koumenis C: Pancreatic cancer cells express 25-hydroxyvitamin D-Ialphahydroxylase and their proliferation is inhibited by the prohormone 25-hydroxyvitamin D3. Carcinogenesis 2004, 25:1015-1026. Epub 2004 Jan 1023.

132. Mawer EB, Hayes ME, Heys SE, Davies M, White A, Stewart MF, Smith GN: Constitutive synthesis of I,25-dihydroxyvitamin D3 by a human small cell lung cancer cell line. J Clin Endocrinol Metab 1994, 79:554-560.

133. Holt PR, Arber N, Halmos B, Forde K, Kissileff H, McGlynn KA, Moss SF, Kurihara N, Fan K, Yang K, Lipkin M: Colonic epithelial cell proliferation decreases with increasing levels of serum 25hydroxy vitamin D. Cancer Epidemiol Biomarkers Prev 2002, I I:I I3-I I9.

134. Barreto AM, Schwartz GG, Woodruff R, Cramer SD: 25-Hydroxyvitamin D3, the prohormone of 1,25-dihydroxyvitamin D3, inhibits the proliferation of primary prostatic epithelial cells. Cancer Epidemiol Biomarkers Prev 2000, 9:265-270.

135. Sunlight, Nutrition And Health Research Center [http:// www.sunarc.org]

136. Hanchette CL, Schwartz GG: Geographic patterns of prostate cancer mortality. Evidence for a protective effect of ultraviolet radiation. Cancer 1992, 70:286 I-2869.

137. Lefkowitz ES, Garland CF: Sunlight, vitamin D, and ovarian cancer mortality rates in US women. Int J Epidemiol 1994, 23: I133-1136.

138. Gorham ED, Garland FC, Garland CF: Sunlight and breast cancer incidence in the USSR. Int J Epidemiol 1990, 19:820-824.

139. Grant WB: Ecologic studies of solar UV-B radiation and cancer mortality rates. Recent Results Cancer Res 2003, 164:37I-377.

140. Grant WB: An estimate of premature cancer mortality in the U.S. due to inadequate doses of solar ultraviolet-B radiation. Cancer 2002, 94:1867-1875.

14I. Hennekens CH, Buring JE, Manson JE, Stampfer M, Rosner B, Cook NR, Belanger C, LaMotte F, Gaziano JM, Ridker PM, Willett W, Peto $\mathrm{R}$ : Lack of effect of long-term supplementation with beta carotene on the incidence of malignant neoplasms and cardiovascular disease. $N$ Engl J Med 1996, 334: I | 45-I | 49.

142. Omenn GS, Goodman GE, Thornquist MD, Balmes J, Cullen MR, Glass A, Keogh JP, Meyskens FL, Valanis B, Williams JH, Barnhart S, Hammar S: Effects of a combination of beta carotene and vitamin A on lung cancer and cardiovascular disease. N Engl J Med 1996, 334: II50-1155.

143. The effect of vitamin $E$ and beta carotene on the incidence of lung cancer and other cancers in male smokers. The Alpha-Tocopherol, Beta Carotene Cancer Prevention Study Group. N Engl J Med 1994, 330: I029-1035.

144. Schuurman AG, Goldbohm RA, Brants HA, van den Brandt PA: A prospective cohort study on intake of retinol, vitamins $C$ and $E$, and carotenoids and prostate cancer risk (Netherlands). Cancer Causes Control 2002, 1 3:573-582.
145. Hsing AW, Comstock GW, Abbey H, Polk BF: Serologic precursors of cancer. Retinol, carotenoids, and tocopherol and risk of prostate cancer. J Natl Cancer Inst 1990, 82:94 I-946.

146. Giovannucci E, Ascherio A, Rimm EB, Stampfer MJ, Colditz GA, Willett WC: Intake of carotenoids and retinol in relation to risk of prostate cancer. J Natl Cancer Inst 1995, 87:I767-1776.

147. Giovannucci E, Rimm EB, Liu Y, Stampfer MJ, Willett WC: A prospective study of tomato products, lycopene, and prostate cancer risk. I Natl Cancer Inst 2002, 94:391-398.

148. Wu K, Erdman JW Jr, Schwartz SJ, Platz EA, Leitzmann M, Clinton SK, DeGroff V, Willett WC, Giovannucci E: Plasma and dietary carotenoids, and the risk of prostate cancer: a nested case-control study. Cancer Epidemiol Biomarkers Prev 2004, I 3:260-269.

149. Gann PH, Ma J, Giovannucci E, Willett W, Sacks FM, Hennekens CH, Stampfer MJ: Lower prostate cancer risk in men with elevated plasma lycopene levels: results of a prospective analysis. Cancer Res 1999, 59:1225-1230.

150. Kucuk O, Sarkar FH, Sakr W, Djuric Z, Pollak MN, Khachik F, Li YW, Banerjee M, Grignon D, Bertram JS, Crissman JD, Pontes EJ, Wood DP Jr: Phase II randomized clinical trial of lycopene supplementation before radical prostatectomy. Cancer Epidemiol Biomarkers Prev 2001, 1 0:861-868.

15I. Bowen P, Chen L, Stacewicz-Sapuntzakis M, Duncan C, Sharifi R, Ghosh L, Kim HS, Christov-Tzelkov K, van Breemen R: Tomato sauce supplementation and prostate cancer: lycopene accumulation and modulation of biomarkers of carcinogenesis. Exp Biol Med (Maywood) 2002, 227:886-893.

152. Fletcher AE, Breeze E, Shetty PS: Antioxidant vitamins and mortality in older persons: findings from the nutrition add-on study to the Medical Research Council Trial of Assessment and Management of Older People in the Community. Am J Clin Nutr 2003, 78:999-1010.

153. Lee KW, Lee HJ, Surh YJ, Lee CY: Vitamin C and cancer chemoprevention: reappraisal. Am J Clin Nutr 2003, 78: I074-1078.

154. Padayatty SJ, Sun H, Wang Y, Riordan HD, Hewitt SM, Katz A, Wesley RA, Levine M: Vitamin C pharmacokinetics: implications for oral and intravenous use. Ann Intern Med 2004, I 40:533-537.

155. Riordan HD, Hunninghake RB, Riordan NH, Jackson JJ, Meng X, Taylor P, Casciari JJ, Gonzalez MJ, Miranda-Massari JR, Mora EM, Rosario $\mathrm{N}$, Rivera $\mathrm{A}$ : Intravenous ascorbic acid: protocol for its application and use. $P$ R Health Sci J 2003, 22:287-290.

156. Riordan NH, Riordan HD, Meng X, Li Y, Jackson JA: Intravenous ascorbate as a tumor cytotoxic chemotherapeutic agent. Med Hypotheses 1995, 44:207-213.

157. Cos P, De Bruyne T, Hermans N, Apers S, Berghe DV, Vlietinck A): Proanthocyanidins in health care: current and new trends. Curr Med Chem 2004, I I: I345-1359.

158. Mukhtar $\mathrm{H}$, Ahmad N: Tea polyphenols: prevention of cancer and optimizing health. Am J Clin Nutr 2000, 7 I:I703S-1694S. discussion I703S-1694S

159. Finegold SM, Sutter VL, Sugihara PT, Elder HA, Lehmann SM, Phillips RL: Fecal microbial flora in Seventh Day Adventist populations and control subjects. Am J Clin Nutr 1977, 30:1781-1792.

160. Moore WE, Moore LH: Intestinal floras of populations that have a high risk of colon cancer. Appl Environ Microbiol 1995 , 61:3202-3207.

16I. Goldin BR, Gorbach SL: The effect of milk and lactobacillus feeding on human intestinal bacterial enzyme activity. $\mathrm{Am}$ Clin Nutr 1984, 39:756-76I.

162. Aso Y, Akazan H: Prophylactic effect of a Lactobacillus casei preparation on the recurrence of superficial bladder cancer. BLP Study Group. Urol Int 1992, 49:125-129.

163. Aso Y, Akaza H, Kotake T, Tsukamoto T, Imai K, Naito S: Preventive effect of a Lactobacillus casei preparation on the recurrence of superficial bladder cancer in a double-blind trial. The BLP Study Group. Eur Urol 1995, 27: 104- 109.

164. Rowland IR, Rumney CJ, Coutts JT, Lievense LC: Effect of Bifidobacterium longum and inulin on gut bacterial metabolism and carcinogen-induced aberrant crypt foci in rats. Carcinogenesis 1998, 19:281-285.

165. Femia AP, Luceri C, Dolara P, Giannini A, Biggeri A, Salvadori M, Clune Y, Collins KJ, Paglierani M, Caderni G: Antitumorigenic activity of the prebiotic inulin enriched with oligofructose in combination with the probiotics Lactobacillus rhamnosus and Bifidobacterium lactis on azoxymethane-induced colon carcinogenesis in rats. Carcinogenesis 2002, 23:1953-1960. 
166. Marotta F, Naito Y, Minelli E, Tajiri H, Bertuccelli J, Wu CC, Min CH, Hotten $P$, Fesce E: Chemopreventive effect of a probiotic preparation on the development of preneoplastic and neoplastic colonic lesions: an experimental study. Hepatogastroenterology 2003, 50:1914-1918.

167. O'Mahony L, Feeney M, O'Halloran S, Murphy L, Kiely B, Fitzgibbon J, Lee G, O'Sullivan G, Shanahan F, Collins JK: Probiotic impact on microbial flora, inflammation and tumour development in IL-10 knockout mice. Aliment Pharmacol Ther 200I, I5:1219-1225.

168. Medhekar R: The first quantitative evidence proving the efficacy of supplemental enzymes. In Forsyth, MO: National Enzyme Company, Inc 2004

169. Rothman S, Liebow C, Isenman L: Conservation of digestive enzymes. Physiol Rev 2002, 82: I- 18.

170. Wald M, Olejar T, Pouckova P, Zadinova M: Proteinases reduce metastatic dissemination and increase survival time in C57B16 mice with the Lewis lung carcinoma. Life Sci 1998, 63:L237-243.

17I. Wald M, Zavadova E, Pouckova P, Zadinova M, Boubelik M: Polyenzyme preparation Wobe-Mugos inhibits growth of solid tumors and development of experimental metastases in mice. Life Sci 1998, 62:L43-48.

172. Desser L, Holomanova D, Zavadova E, Pavelka K, Mohr T, Herbacek I: Oral therapy with proteolytic enzymes decreases excessive TGF-beta levels in human blood. Cancer Chemother Pharmacol 200I, 47:SI0-I5.

173. Lauer D, Muller R, Cott C, Otto A, Naumann M, Birkenmeier G: Modulation of growth factor binding properties of alpha2 macroglobulin by enzyme therapy. Cancer Chemother Pharmacol 200I, 47:54-9.

174. Sakalova A, Bock PR, Dedik L, Hanisch J, Schiess W, Gazova S, Chabronova I, Holomanova D, Mistrik M, Hrubisko M: Retrolective cohort study of an additive therapy with an oral enzyme preparation in patients with multiple myeloma. Cancer Chemother Pharmacol 200I, 47:S38-44.

175. Dale PS, Tamhankar CP, George D, Daftary GV: Co-medication with hydrolytic enzymes in radiation therapy of uterine cervix: evidence of the reduction of acute side effects. Cancer Chemother Pharmacol 200I, 47:S29-34.

176. Gujral MS, Patnaik PM, Kaul R, Parikh HK, Conradt C, Tamhankar CP, Daftary GV: Efficacy of hydrolytic enzymes in preventing radiation therapy-induced side effects in patients with head and neck cancers. Cancer Chemother Pharmacol 200I, 47:523-28.

177. Popiela T, Kulig J, Hanisch J, Bock PR: Influence of a complementary treatment with oral enzymes on patients with colorectal cancers - an epidemiological retrolective cohort study. Cancer Chemother Pharmacol 200I, 47:S55-63.

178. Beuth J, Ost B, Pakdaman A, Rethfeldt E, Bock PR, Hanisch J, Schneider $B$ : Impact of complementary oral enzyme application on the postoperative treatment results of breast cancer patients - results of an epidemiological multicentre retrolective cohort study. Cancer Chemother Pharmacol 200I, 47:S45-54.

179. Hildenbrand GL, Hildenbrand LC, Bradford K, Cavin SW: Five-year survival rates of melanoma patients treated by diet therapy after the manner of Gerson: a retrospective review. Altern Ther Health Med 1995, I:29-37.

180. Sieri S, Krogh V, Pala V, Muti P, Micheli A, Evangelista A, Tagliabue G, Berrino F: Dietary patterns and risk of breast cancer in the ORDET cohort. Cancer Epidemiol Biomarkers Prev 2004, I 3:567-572.

18I. Rock CL, Flatt SW, Thomson CA, Stefanick ML, Newman VA, Jones L, Natarajan L, Pierce JP, Chang RJ, Witztum JL: Plasma triacylglycerol and HDL cholesterol concentrations confirm selfreported changes in carbohydrate and fat intakes in women in a diet intervention trial. I Nutr 2004, 134:342-347.

182. Pierce JP, Newman VA, Flatt SW, Faerber S, Rock CL, Natarajan L, Caan B], Gold EB, Hollenbach KA, Wasserman L, Jones L, Ritenbaugh C, Stefanick ML, Thomson CA, Kealey S: Telephone counseling intervention increases intakes of micronutrient- and phytochemical-rich vegetables, fruit and fiber in breast cancer survivors. I Nutr 2004, I34:452-458.

183. Goodstine SL, Zheng T, Holford TR, Ward BA, Carter D, Owens PH, Mayne ST: Dietary $(n-3) /(n-6)$ fatty acid ratio: possible relationship to premenopausal but not postmenopausal breast cancer risk in U.S. women. J Nutr 2003, I33:|409-|4|4.

184. Simonsen N, van't Veer P, Strain J], Martin-Moreno JM, Huttunen JK, Navajas JF, Martin BC, Thamm M, Kardinaal AF, Kok FJ, Kohlmeier L:
Adipose tissue omega-3 and omega- 6 fatty acid content and breast cancer in the EURAMIC study. European Community Multicenter Study on Antioxidants, Myocardial Infarction, and Breast Cancer. Am J Epidemiol 1998, I 47:342-352.

185. Maillard V, Bougnoux P, Ferrari P, Jourdan ML, Pinault M, Lavillonniere F, Body G, Le Floch O, Chajes V: N-3 and N-6 fatty acids in breast adipose tissue and relative risk of breast cancer in a case-control study in Tours, France. Int J Cancer 2002, 98:78-83.

186. Bagga D, Anders KH, Wang HJ, Glaspy JA: Long-chain n-3-to-n-6 polyunsaturated fatty acid ratios in breast adipose tissue from women with and without breast cancer. Nutr Cancer 2002, 42:180-185

187. Pala V, Krogh V, Muti P, Chajes V, Riboli E, Micheli A, Saadatian M, Sieri S, Berrino F: Erythrocyte membrane fatty acids and subsequent breast cancer: a prospective Italian study. I Natl Cancer Inst 200I, 93: I088-1095.

188. Gago-Dominguez M, Yuan JM, Sun CL, Lee HP, Yu MC: Opposing effects of dietary n-3 and n-6 fatty acids on mammary carcinogenesis: The Singapore Chinese Health Study. Br J Cancer 2003, 89:1686-1692.

189. Li H, Stampfer MJ, Giovannucci EL, Morris JS, Willett WC, Gaziano JM, Ma J: A prospective study of plasma selenium levels and prostate cancer risk. I Natl Cancer Inst 2004, 96:696-703.

190. van den Brandt PA, Zeegers MP, Bode P, Goldbohm RA: Toenail selenium levels and the subsequent risk of prostate cancer: a prospective cohort study. Cancer Epidemiol Biomarkers Prev 2003. | 2:866-87|.

191. Brooks JD, Metter EJ, Chan DW, Sokoll LJ, Landis P, Nelson WG, Muller D, Andres R, Carter HB: Plasma selenium level before diagnosis and the risk of prostate cancer development. J Urol 200I, 166:2034-2038.

192. Helzlsouer KJ, Huang HY, Alberg AJ, Hoffman S, Burke A, Norkus EP, Morris JS, Comstock GW: Association between alpha-tocopherol, gamma-tocopherol, selenium, and subsequent prostate cancer. J Natl Cancer Inst 2000, 92:2018-2023.

193. Yoshizawa K, Willett WC, Morris SJ, Stampfer MJ, Spiegelman D, Rimm EB, Giovannucci E: Study of prediagnostic selenium level in toenails and the risk of advanced prostate cancer. J Nat Cancer Inst 1998, 90: 1219-1224.

194. Criqui MH, Bangdiwala S, Goodman DS, Blaner WS, Morris JS, Kritchevsky S, Lippel K, Mebane I, Tyroler HA: Selenium, retinol, retinol-binding protein, and uric acid. Associations with cancer mortality in a population-based prospective case-control study. Ann Epidemiol 1991, I:385-393.

195. Lashner BA, Heidenreich PA, Su GL, Kane SV, Hanauer SB: Effect of folate supplementation on the incidence of dysplasia and cancer in chronic ulcerative colitis. A case-control study. Gastroenterology 1989, 97:255-259.

196. Freudenheim JL, Graham S, Marshall JR, Haughey BP, Cholewinski S, Wilkinson G: Folate intake and carcinogenesis of the colon and rectum. Int J Epidemiol I99I, 20:368-374.

197. Benito E, Stiggelbout A, Bosch FX, Obrador A, Kaldor J, Mulet M, Munoz N: Nutritional factors in colorectal cancer risk: a casecontrol study in Majorca. Int J Cancer I99I, 49:16I-167.

198. Meyer $\mathrm{F}$, White $\mathrm{E}$ : Alcohol and nutrients in relation to colon cancer in middle-aged adults. Am J Epidemiol 1993, 138:225-236.

199. Giovannucci E, Stampfer MJ, Colditz GA, Rimm EB, Trichopoulos D, Rosner BA, Speizer FE, Willett WC: Folate, methionine, and alcohol intake and risk of colorectal adenoma. J Natl Cancer Inst 1993, 85:875-884.

200. Ferraroni M, La Vecchia C, D'Avanzo B, Negri E, Franceschi S, Decarli $A$ : Selected micronutrient intake and the risk of colorectal cancer. Br J Cancer 1994, 70: I I50-I I 55.

20I. Giovannucci E, Rimm EB, Ascherio A, Stampfer MJ, Colditz GA, Willett WC: Alcohol, low-methionine - low-folate diets, and risk of colon cancer in men. J Natl Cancer Inst 1995, 87:265-273.

202. Glynn SA, Albanes D, Pietinen P, Brown CC, Rautalahti M, Tangrea JA, Gunter EW, Barrett MJ, Virtamo J, Taylor PR: Colorectal cancer and folate status: a nested case-control study among male smokers. Cancer Epidemiol Biomarkers Prev 1996, 5:487-494.

203. Slattery ML, Schaffer D, Edwards SL, Ma KN, Potter JD: Are dietary factors involved in DNA methylation associated with colon cancer? Nutr Cancer 1997, 28:52-62.

204. Giovannucci E, Stampfer MJ, Colditz GA, Hunter DJ, Fuchs C, Rosner BA, Speizer FE, Willett WC: Multivitamin use, folate, and colon 
cancer in women in the Nurses' Health Study. Ann Intern Med 1998, I 29:517-524.

205. Kato I, Dnistrian AM, Schwartz M, Toniolo P, Koenig K, Shore RE, Akhmedkhanov A, Zeleniuch-Jacquotte A, Riboli E: Serum folate, homocysteine and colorectal cancer risk in women: a nested case-control study. Br J Cancer 1999, 79:1917-1922.

206. Su LJ, Arab L: Nutritional status of folate and colon cancer risk: evidence from NHANES I epidemiologic follow-up study. Ann Epidemiol 200I, I I:65-72.

207. Fuchs CS, Willett WC, Colditz GA, Hunter DJ, Stampfer MJ, Speizer $\mathrm{FE}$, Giovannucci EL: The influence of folate and multivitamin use on the familial risk of colon cancer in women. Cancer Epidemiol Biomarkers Prev 2002, I I:227-234.

208. Terry P, Jain M, Miller AB, Howe GR, Rohan TE: Dietary intake of folic acid and colorectal cancer risk in a cohort of women. Int J Cancer 2002, 97:864-867.

209. Konings EJ, Goldbohm RA, Brants HA, Saris WH, van den Brandt PA: Intake of dietary folate vitamers and risk of colorectal carcinoma: results from The Netherlands Cohort Study. Cancer 2002, 95:|42|-| 433

210. La Vecchia C, Negri E, Pelucchi C, Franceschi S: Dietary folate and colorectal cancer. Int J Cancer 2002, 102:545-547.

21 I. Harnack L, Jacobs DR Jr, Nicodemus K, Lazovich D, Anderson K, Folsom AR: Relationship of folate, vitamin B-6, vitamin B-12, and methionine intake to incidence of colorectal cancers. Nutr Cancer 2002, 43: I52-158.

212. Satia-Abouta J, Galanko JA, Martin CF, Potter JD, Ammerman A, Sander RS: Associations of micronutrients with colon cancer risk in African Americans and whites: results from the North Carolina Colon Cancer Study. Cancer Epidemiol Biomarkers Prev 2003, I 2:747-754.

213. Martinez ME, Henning SM, Alberts DS: Folate and colorectal neoplasia: relation between plasma and dietary markers of folate and adenoma recurrence. Am J Clin Nutr 2004, 79:69I-697.

214. Zhang S, Hunter DJ, Hankinson SE, Giovannucci EL, Rosner BA, Colditz GA, Speizer FE, Willett WC: A prospective study of folate intake and the risk of breast cancer. Jama 1999, 28 I:1632-1637.

215. Rohan TE, Jain MG, Howe GR, Miller AB: Dietary folate consumption and breast cancer risk. I Natl Cancer Inst 2000, 92:266-269.

216. Sellers TA, Kushi LH, Cerhan JR, Vierkant RA, Gapstur SM, Vachon CM, Olson JE, Therneau TM, Folsom AR: Dietary folate intake, alcohol, and risk of breast cancer in a prospective study of postmenopausal women. Epidemiology 200I, I 2:420-428.

217. Cho E, Spiegelman D, Hunter DJ, Chen WY, Zhang SM, Colditz GA, Willett WC: Premenopausal intakes of vitamins A, C, and E, folate, and carotenoids, and risk of breast cancer. Cancer Epidemiol Biomarkers Prev 2003, I 2:713-720.

218. Sellers TA, Grabrick DM, Vierkant RA, Harnack L, Olson JE, Vachon CM, Cerhan JR: Does folate intake decrease risk of postmenopausal breast cancer among women with a family history? Cancer Causes Control 2004, I5: I I3-120.

219. Garland C, Shekelle RB, Barrett-Connor E, Criqui MH, Rossof AH, Paul O: Dietary vitamin D and calcium and risk of colorectal cancer: a 19-year prospective study in men. Lancet 1985, I:307-309

220. Garland CF, Comstock GW, Garland FC, Helsing KJ, Shaw EK, Gorham ED: Serum 25-hydroxyvitamin $D$ and colon cancer: eight-year prospective study. Lancet 1989, 2:1 | 76 - I I 78 .

22I. Gann PH, Ma J, Hennekens CH, Hollis BW, Haddad JG, Stampfer MJ: Circulating vitamin $D$ metabolites in relation to subsequent development of prostate cancer. Cancer Epidemiol Biomarkers Prev 1996, 5:121-126.

222. Martinez ME, Giovannucci EL, Colditz GA, Stampfer MJ, Hunter DJ, Speizer FE, Wing A, Willett WC: Calcium, vitamin D, and the occurrence of colorectal cancer among women. J Natl Cancer Inst 1996, 88: I 375-1382.

223. Tangrea J, Helzlsouer K, Pietinen P, Taylor P, Hollis B, Virtamo J, Albanes D: Serum levels of vitamin $D$ metabolites and the subsequent risk of colon and rectal cancer in Finnish men. Cancer Causes Control 1997, 8:615-625.

224. John EM, Schwartz GG, Dreon DM, Koo J: Vitamin D and breast cancer risk: the NHANES I Epidemiologic follow-up study, | 97 |-1975 to 1992. National Health and Nutrition Examination Survey. Cancer Epidemiol Biomarkers Prev 1999, 8:399-406.
225. Ahonen MH, Tenkanen L, Teppo L, Hakama M, Tuohimaa P: Prostate cancer risk and prediagnostic serum 25-hydroxyvitamin D levels (Finland). Cancer Causes Control 2000, I I:847-852.

226. Grau MV, Baron JA, Sandler RS, Haile RW, Beach ML, Church TR, Heber D: Vitamin D, calcium supplementation, and colorectal adenomas: results of a randomized trial. J Natl Cancer Inst 2003, 95: |765-|77|.

227. Tuohimaa $P$, Tenkanen L, Ahonen M, Lumme S, Jellum E, Hallmans G, Stattin P, Harvei S, Hakulinen T, Luostarinen T, Dillner J, Lehtinen M, Hakama M: Both high and low levels of blood vitamin D are associated with a higher prostate cancer risk: a longitudinal, nested case-control study in the Nordic countries. Int J Cancer 2004, 108:104-108.

228. Le Marchand L, Hankin JH, Kolonel LN, Beecher GR, Wilkens LR, Zhao LP: Intake of specific carotenoids and lung cancer risk. Cancer Epidemiol Biomarkers Prev 1993, 2:183-187.

229. Comstock GW, Alberg AJ, Huang HY, Wu K, Burke AE, Hoffman SC, Norkus EP, Gross M, Cutler RG, Morris JS, Spate VL, Helzlsouer KJ: The risk of developing lung cancer associated with antioxidants in the blood: ascorbic acid, carotenoids, alpha-tocopherol, selenium, and total peroxyl radical absorbing capacity. Cancer Epidemiol Biomarkers Prev 1997, 6:907-916.

230. Garcia-Closas R, Agudo A, Gonzalez CA, Riboli E: Intake of specific carotenoids and flavonoids and the risk of lung cancer in women in Barcelona, Spain. Nutr Cancer 1998, 32:154- I58.

23I. Stefani ED, Boffetta P, Deneo-Pellegrini H, Mendilaharsu M, Carzoglio JC, Ronco A, Olivera L: Dietary antioxidants and lung cancer risk: a case-control study in Uruguay. Nutr Cancer 1999, 34: $100-110$

232. Knekt P, Jarvinen R, Teppo L, Aromaa A, Seppanen R: Role of various carotenoids in lung cancer prevention. I Natl Cancer Inst 1999, $91: 182-184$.

233. Michaud DS, Feskanich D, Rimm EB, Colditz GA, Speizer FE, Willett WC, Giovannucci E: Intake of specific carotenoids and risk of lung cancer in 2 prospective US cohorts. Am J Clin Nutr 2000, 72:990-997.

234. Yuan JM, Ross RK, Chu XD, Gao YT, Yu MC: Prediagnostic levels of serum beta-cryptoxanthin and retinol predict smokingrelated lung cancer risk in Shanghai, China. Cancer Epidemiol Biomarkers Prev 200I, 10:767-773.

235. Rohan TE, Jain M, Howe GR, Miller AB: A cohort study of dietary carotenoids and lung cancer risk in women (Canada). Cancer Causes Control 2002, I3:231-237.

236. Ito Y, Wakai K, Suzuki K, Tamakoshi A, Seki N, Ando M, Nishino Y, Kondo T, Watanabe Y, Ozasa K, Ohno Y: Serum carotenoids and mortality from lung cancer: a case-control study nested in the Japan Collaborative Cohort (JACC) study. Cancer Sci 2003, 94:57-63.

237. Yuan JM, Stram DO, Arakawa K, Lee HP, Yu MC: Dietary cryptoxanthin and reduced risk of lung cancer: the Singapore Chinese Health Study. Cancer Epidemiol Biomarkers Prev 2003 I 2:890-898.

238. Mannisto S, Smith-Warner SA, Spiegelman D, Albanes D, Anderson $K$, van den Brandt PA, Cerhan JR, Colditz G, Feskanich D, Freudenheim JL, Giovannucci E, Goldbohm RA, Graham S, Miller AB, Rohan TE, Virtamo J, Willett WC, Hunter DJ: Dietary carotenoids and risk of lung cancer in a pooled analysis of seven cohort studies. Cancer Epidemiol Biomarkers Prev 2004, 1 3:40-48.

Publish with Bio Med Central and every scientist can read your work free of charge

"BioMed Central will be the most significant development for disseminating the results of biomedical research in our lifetime. "

Sir Paul Nurse, Cancer Research UK

Your research papers will be:

- available free of charge to the entire biomedical community

- peer reviewed and published immediately upon acceptance

- cited in PubMed and archived on PubMed Central

- yours - you keep the copyright 